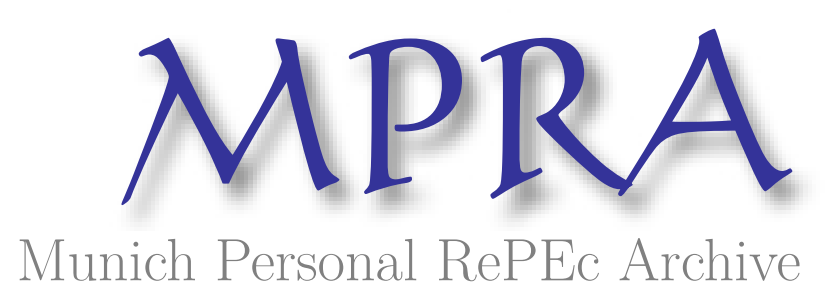

\title{
GLOBAL OPPORTUNITY INDEX 2021 Focus on Latin America
}

Contreras, Oscar and Smith, Benjamin and Bendix, Joseph and Lopez, Claude

Milken Institute, Milken Institute, Milken Institute

4 February 2021

Online at https://mpra.ub.uni-muenchen.de/105787/

MPRA Paper No. 105787, posted 08 Feb 2021 11:11 UTC 


\section{GLOBAL OPPORTUNITY INDEX 2021 Focus on Latin America}

Oscar Contreras, Ph.D., Joseph Bendix, Benjamin Smith, and Claude Lopez, Ph.D. 


\section{Contents}

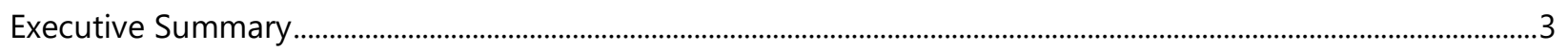

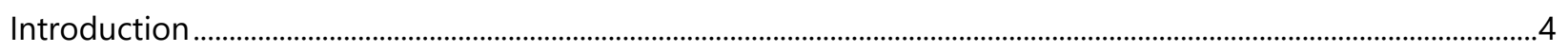

Section 1. Latin America Performance in GOI 2021 ..................................................................................................

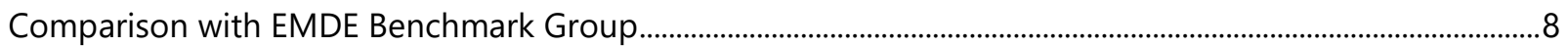

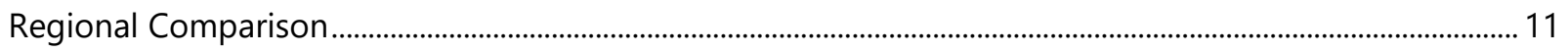

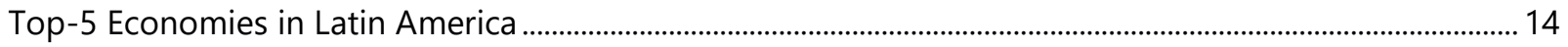

Section 2. Recent Trends in Private Cross-Border Capital Flows to Latin America ............................................... 17

Components of Private Cross-Border Capital Inflows .............................................................................................. 19

Composition of Private Cross-Border Capital Inflows ………………………………................................................. 21

Heterogeneity in Private Cross-Border Capital Inflows ............................................................................................. 22

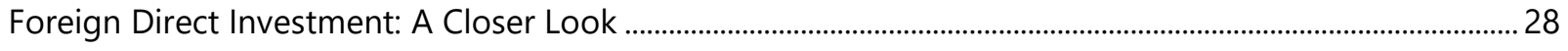

Section 3. Cross-Border Mergers and Acquisitions in Latin America ....................................................................... 32

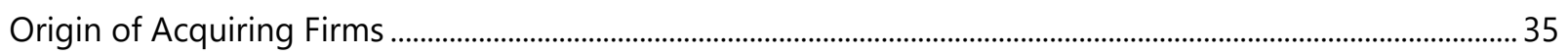

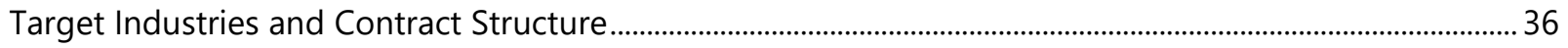

Deal-Making Process: The "ABCD" Companies in Latin America ...................................................................... 37

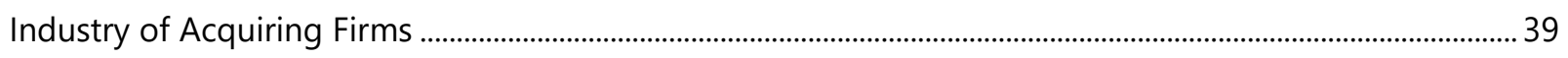

Conclusion: The Road Ahead ................................................................................................................................... 40

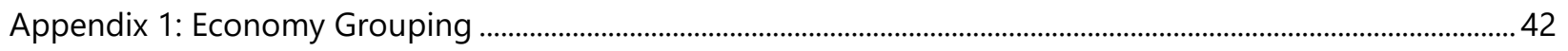

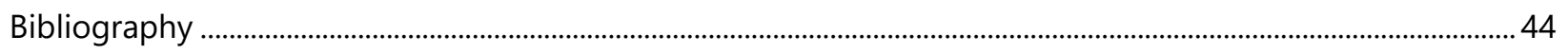

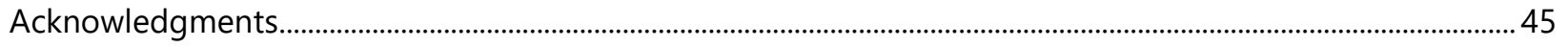

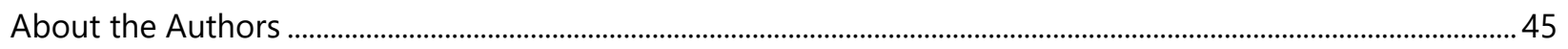




\section{Executive Summary}

This report uses the 2021 Global Opportunity Index and its different categories to provide an overview of Latin America's attractiveness to foreign investors, especially when compared to other emerging markets and developing economies. It also offers an in-depth look at Latin America's global capital inflows (emphasizing their composition and evolution over the past decade) and the regions' cross-border M\&A activity.

The report sheds light on Latin America's declining ability to attract foreign capital over the past decade and, by doing so, helps to identify areas of opportunity to improve foreign investors' perception of the region.

The analysis shows that when it comes to attracting foreign investors, Latin American countries compare well with other emerging markets and developing economies in the following categories:

- Workforce Talent, which captures the qualifications and diversity of the labor force.

- Financial Size and Condition, which reflects the breadth and depth of the existing financial system.

However, Latin America underperforms relative to other emerging markets and developing economies in two key areas:

- Business Constraints, including the cost and time required to start a new business, and the percentage of firms that identify corruption, labor regulations, and taxes as an impediment to business.

- Investors' Rights, which account for the strength of investors' protection, property rights, and instability in government policymaking.

Overall, the report highlights that many of the main challenges to foreign investors (and, more broadly, to a sound investment climate in the region) stem from the lack of a strong, transparent, and predictable legal framework, including well-functioning legal and judicial systems. Thus, the analysis suggests that Latin American governments must take concrete measures to strengthen the rule of law and tackle the pervasive corruption that undermines public trust. 


\section{Introduction}

Access to foreign capital can play a crucial role in promoting economic growth and development in Latin America. If accompanied by sound policies, the flow of international capital to the region can not only supplement insufficient domestic savings, create new jobs, and increase a country's productive capacity, but it can also introduce new technologies (including management and organizational practices) and foster competition and innovation among local firms.

Yet Latin America's ability to attract foreign capital has declined over time, affecting its relative position among emerging markets and developing economies. Between 2010 and 2014, the region attracted 28 percent of total global flows directed to these economies, making Latin America the largest recipient among this group of countries. But that fraction decreased to about 22 percent during the 2015-2019 period, below that of China (30 percent) and other emerging and developing Asian countries (24 percent).

Whether Latin America can regain its status and become, once again, the primary destination of capital flows among emerging markets and developing economies will depend on its ability to improve foreign investors' perception of the region. In turn, this will depend on Latin America's ability to identify areas of opportunity (relative to its peers) and undertake the appropriate reforms.

This report uses the 2021 Global Opportunity Index and its different categories to provide an overview of Latin America's attractiveness to foreign investors, particularly when compared to other emerging markets and developing economies. The Global Opportunity Index, which provides foreign investors with a broad outlook of a country's investment landscape, is based on a combination of 96 variables organized around five broad categories (each one capturing a different aspect of the country's investment climate): Business Perception, Economic Fundamentals, Financial Services, Institutional Framework, and International Standards \& Policy. ${ }^{1}$ The report also offers an in-depth look at global capital inflows to Latin America (emphasizing their composition and evolution over the past decade) and the regions' M\&A landscape.

\footnotetext{
${ }^{1}$ For more details on the Global Opportunity Index, see Smith (2021).
} 
The analysis illustrates that Latin American countries perform well relative to other emerging markets and developing economies in two areas. The first is Economic Fundamentals-particularly Workforce Talent, which accounts for labor force participation, and the workforce's qualifications and diversity. The second is Financial Services-especially Financial Size and Condition, which reflects the existing financial system's breadth and depth.

By contrast, Latin America lags behind other emerging markets and developing economies in two crucial categories. The first is Business Perception-especially Business Constraints, which include the cost and time required to start a new business and the percentage of firms that identify corruption, labor regulations, and taxes as an impediment to business. The second is Institutional Framework-particularly Investors' Rights, which account for the strength of investors' rights, protection of property rights, and instability in government policymaking.

Overall, the report highlights that a sound macroeconomic framework, such as the one achieved by many of the region's economies, is necessary but not sufficient to attract foreign investors. A healthy investment climate also requires a robust, transparent, and predictable legal framework, including wellfunctioning legal and judicial systems.

There is no single recipe for success when it comes to attracting and retaining foreign investors. But the report suggests that most Latin American economies would greatly benefit from taking concrete measures to strengthen the rule of law and tackle the pervasive corruption that continues to undermine public trust. 


\section{Section 1. Latin America Performance in GOI 2021}

Figure 1.1 shows the ranking of the 20 Latin American (LATAM) countries in the Global Opportunity Index, 2021.

With over 100 positions separating the best and worst ranked country, it is clear that the LATAM region offers a diversity of opportunities for foreign investors.

This heterogeneity becomes more apparent when the Index is disaggregated into its five constituent categories and fourteen sub-categories. These categories capture economic, financial, legal, regulatory, and institutional factors that, when taken together, offer a holistic view of a country's investment landscape.

- Business Perception - measures the constraints facing businesses and the ease for businesses to resolve disputes.

- Recovery \& Resolution Process

- Business Constraint 
- Economic Fundamentals - captures a country's macroeconomic outlook, workforce talent, and potential for future innovation and development.

- Future Environment of Growth

- Economic Performance

- Workforce Talent

- Financial Services - measures the depth and breadth of a country's access to financial services.

- Financial Access

- Financial Size \& Condition

- Institutional Framework - captures the extent to which a country's institutions help or hinder business activity.

- Transparency

- Innovation

- Investors' Rights

- Public Governance

- International Standards \& Policy - measures how integrated a country is within the international community and the likelihood they will conform to international standards.

- Economic Openness

- Tax \& Regulation

○ Patent \& Trademark

\section{Figure 1.1: GOI 2021 Ranking}




\begin{tabular}{|c|c|c|c|c|c|c|}
\hline & $\begin{array}{l}\text { Business } \\
\text { Perception }\end{array}$ & $\begin{array}{l}\text { Economic } \\
\text { Fundamentals }\end{array}$ & $\begin{array}{l}\text { Financial } \\
\text { Services }\end{array}$ & $\begin{array}{l}\text { Institutional } \\
\text { Framework }\end{array}$ & $\begin{array}{l}\text { International } \\
\text { Standards \& } \\
\text { Policy }\end{array}$ & $\begin{array}{l}\text { Total } \\
\text { Index } \\
\text { Ranking }\end{array}$ \\
\hline Argentina & 119 & 82 & 80 & 95 & 69 & 88 \\
\hline Belize & 127 & 93 & 72 & 111 & 145 & 118 \\
\hline Bolivia & 130 & 86 & 64 & 140 & 119 & 113 \\
\hline Brazil & 120 & 62 & 41 & 70 & 92 & 76 \\
\hline Chile & 51 & 50 & 29 & 30 & 39 & 36 \\
\hline Colombia & 106 & 64 & 69 & 58 & 50 & 68 \\
\hline Costa Rica & 92 & 48 & 45 & 44 & 59 & 55 \\
\hline Ecuador & 138 & 76 & 81 & 108 & 116 & 111 \\
\hline El Salvador & 102 & 95 & 82 & 118 & 108 & 99 \\
\hline Guatemala & 123 & 101 & 88 & 106 & 77 & 97 \\
\hline Guyana & 91 & 125 & 101 & 101 & 101 & 104 \\
\hline Honduras & 139 & 104 & 86 & 98 & 121 & 117 \\
\hline Mexico & 67 & 85 & 78 & 59 & 49 & 64 \\
\hline Nicaragua & 85 & 106 & 97 & 131 & 86 & 100 \\
\hline Panama & 65 & 71 & 46 & 80 & 82 & 65 \\
\hline Paraguay & 110 & 75 & 95 & 117 & 76 & 93 \\
\hline Peru & 100 & 61 & 63 & 69 & 47 & 66 \\
\hline Suriname & 137 & 102 & 103 & 128 & 118 & 126 \\
\hline Uruguay & 70 & 60 & 44 & 29 & 55 & 48 \\
\hline Venezuela & 144 & 129 & 77 & 145 & 112 & 137 \\
\hline
\end{tabular}

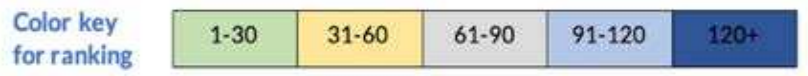

Source: Milken Institute, Global Opportunity Index (2021)

\section{Comparison with EMDE Benchmark Group}

To better gauge the LATAM region's investment opportunities, it is useful to compare its performance with a benchmark group. We use countries classified as emerging markets and developing economies (EMDE) by the IMF as this benchmark, with the similarities in development indicators establishing a fair baseline for comparison. ${ }^{2}$

\footnotetext{
${ }^{2}$ The IMF sorts the world into advanced and EMDE countries based upon a countries per capita income, export diversification, and degree of integration into the global financial system (see Appendix 1). Of the total 145 countries included in the GOI 2021, 109 countries are categorized as EMDE, and 36 are advanced economies. All 20 of the LATAM countries included in this report are classified as EMDE.
} 
Figure 1.2 shows that Chile, Costa Rica, and Uruguay perform better than the rest of the LATAM countries. Conversely, Venezuela performs the worst. The remaining 16 countries are comparable to the average EMDE score.

Overall, the LATAM region's performance is more homogenous than the EMDE group (see figure 1.3). Countries from the region perform better than the benchmark group in Economic Fundamentals, Financial Services, and International Standards \& Policy. They underperform the benchmark in Business Perception and Institutional Framework.

\section{Figure 1.2: Comparing LATAM Countries with EMDE benchmark}

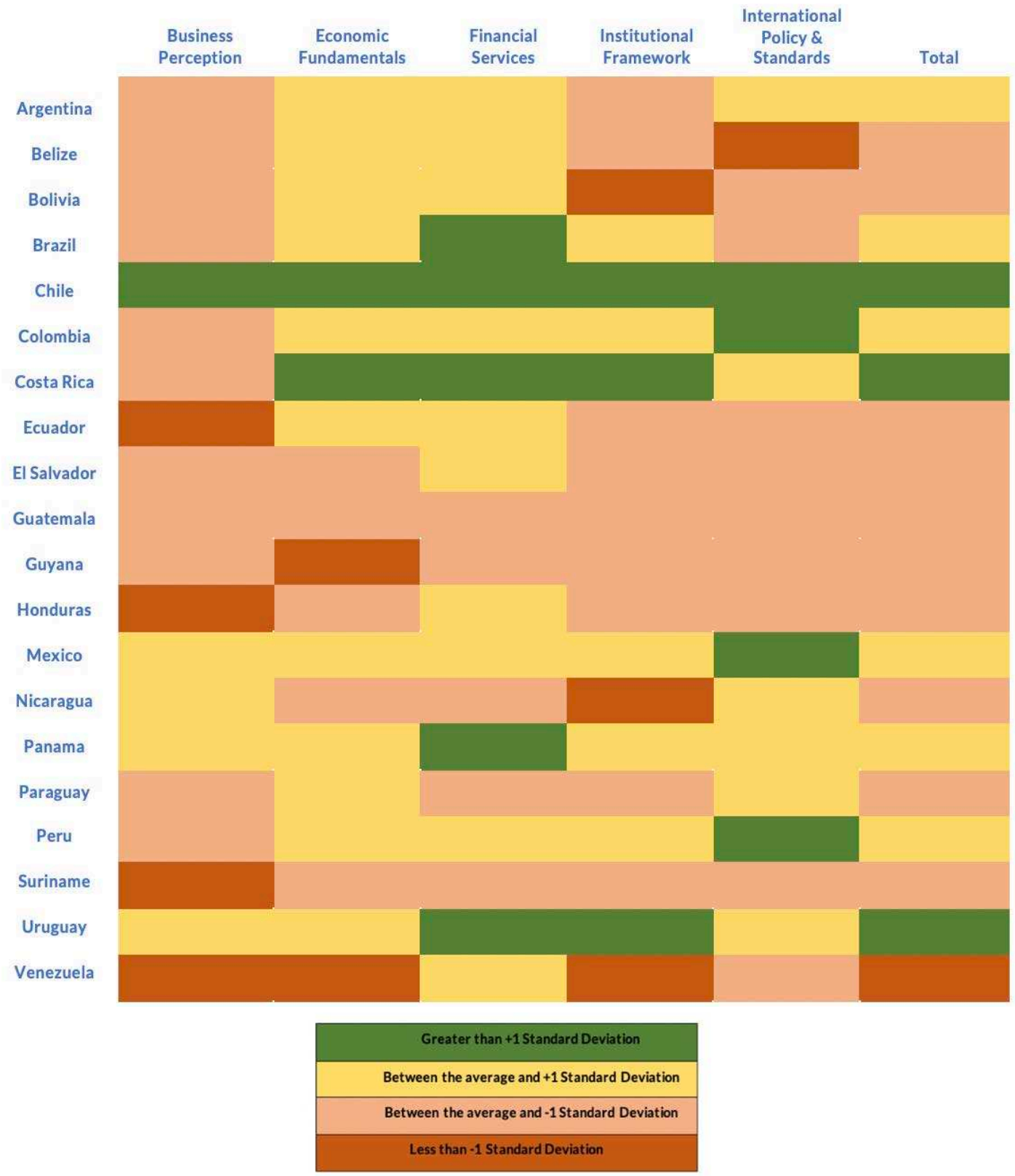

Note: Values are compared against the mean value of the 109 countries included in the EMDE benchmark group. 
Source: Authors' calculations based on Global Opportunity Index (2021)

\section{Figure 1.3: LATAM Region performance against EMDE Benchmark, category level}

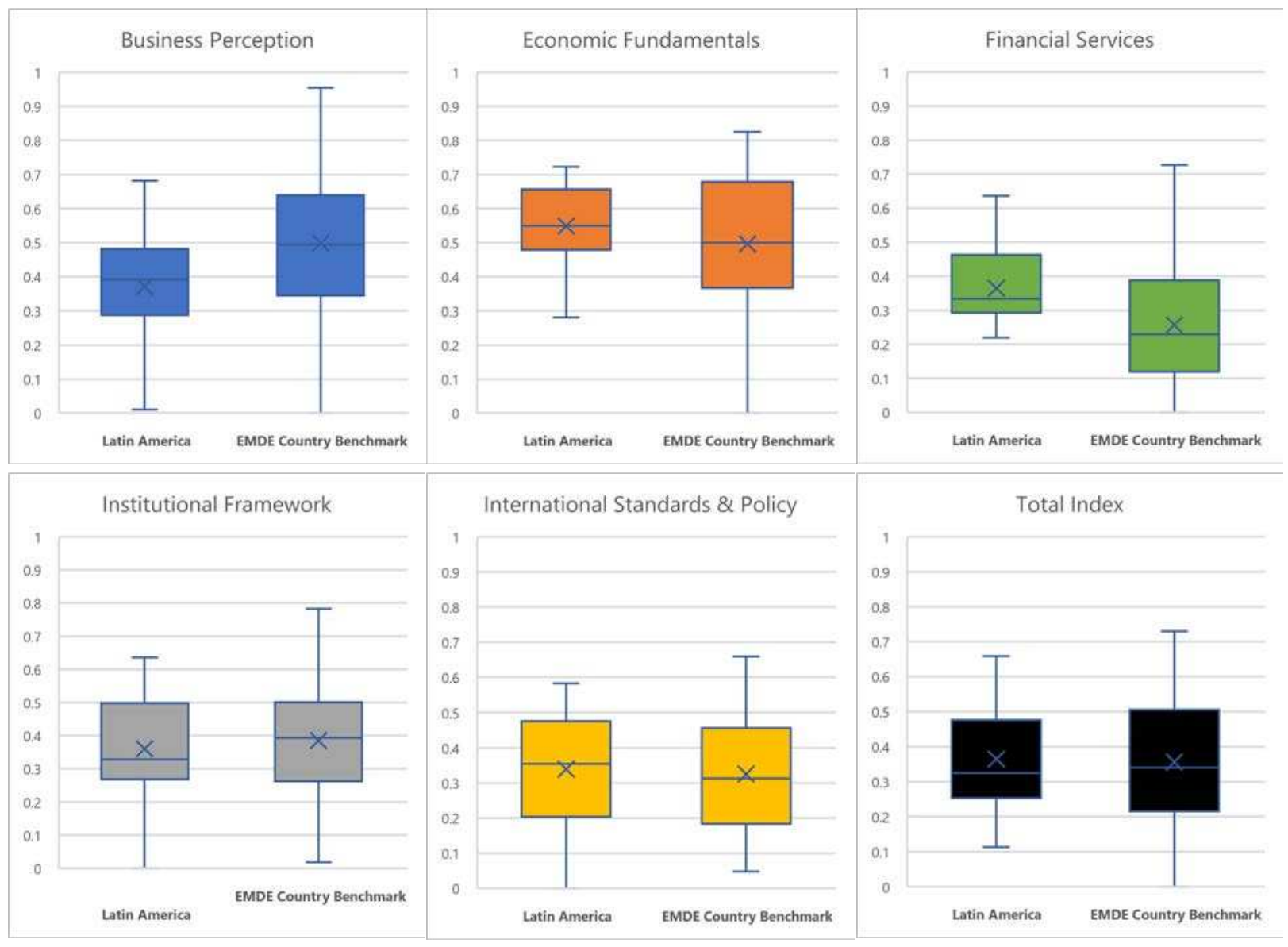

Source: Authors' calculations based on Global Opportunity Index (2021) 
Figure 1.4: LATAM Region compared against EMDE regional groupings, category level

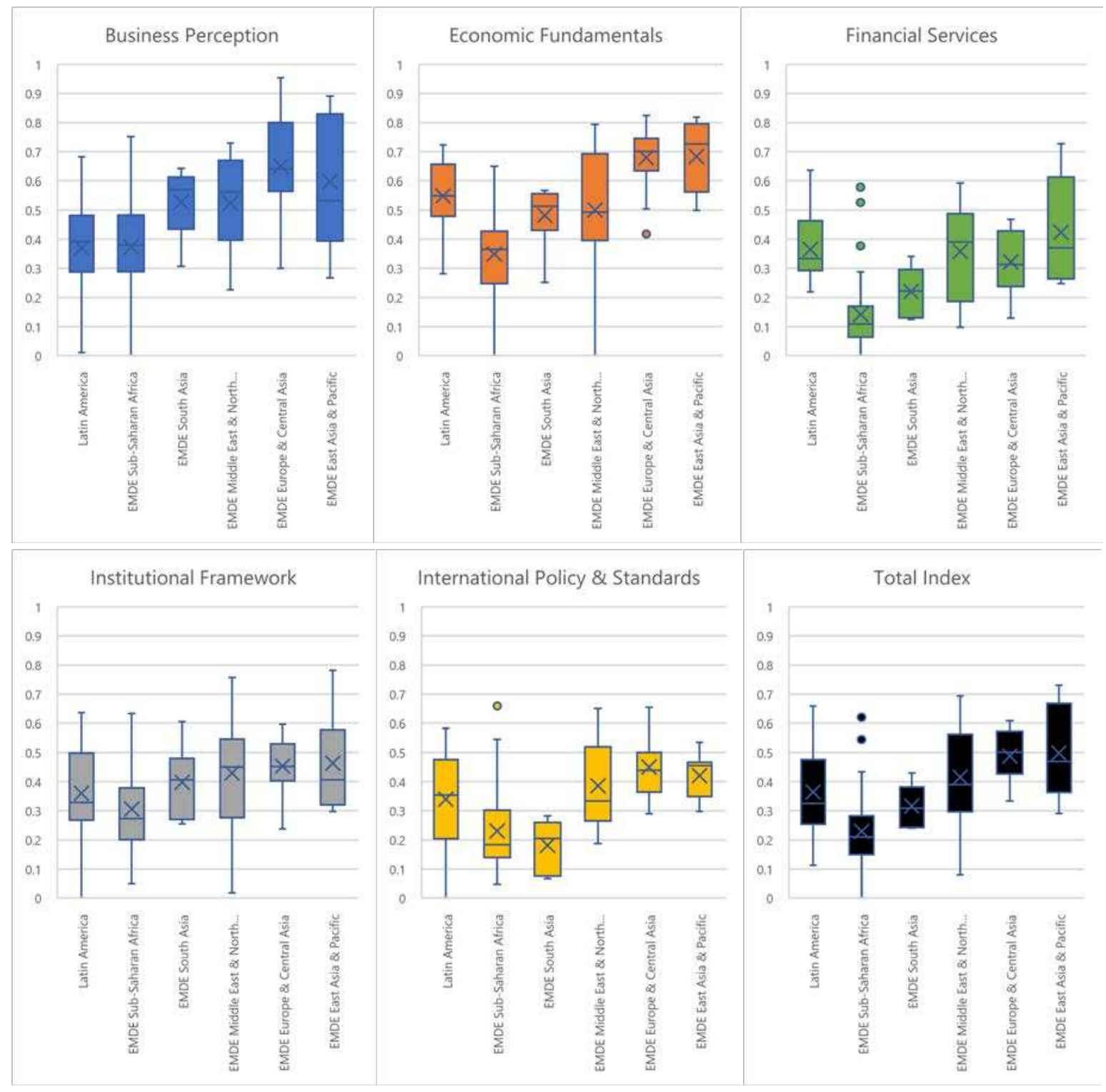

Note: Caribbean countries are not included as a regional grouping due to insufficient sample size.

Source: Authors' calculations based on Global Opportunity Index (2021)

\section{Regional Comparison}

Disaggregating the EMDE benchmark group by geographic region shows that LATAM compares well with South Asia and only slightly underperforms the Middle East \& North Africa region (see figure 1.4). 
At the category level, Latin America is impressive in Economic Fundamentals and Financial Services. In these two categories, it scores higher than all of the other regions excluding Europe $\&$ Central Asia, and East Asia \& Pacific.

The LATAM region underperforms in Business Perception and Institutional Framework, with only EMDE countries from Sub-Saharan Africa scoring worse. The region has a mixed performance in International Policy \& Standards, with a performance comparable to the Middle East \& North Africa and the highest variance among all of the categories. Therefore, heterogeneity in the LATAM region is most apparent in how countries conform to international standards and how they have integrated within the international community using statecraft tools such as trade agreements and investment treaties.

Figure 1.5: LATAM Region compared against EMDE regional groupings, sub-category level
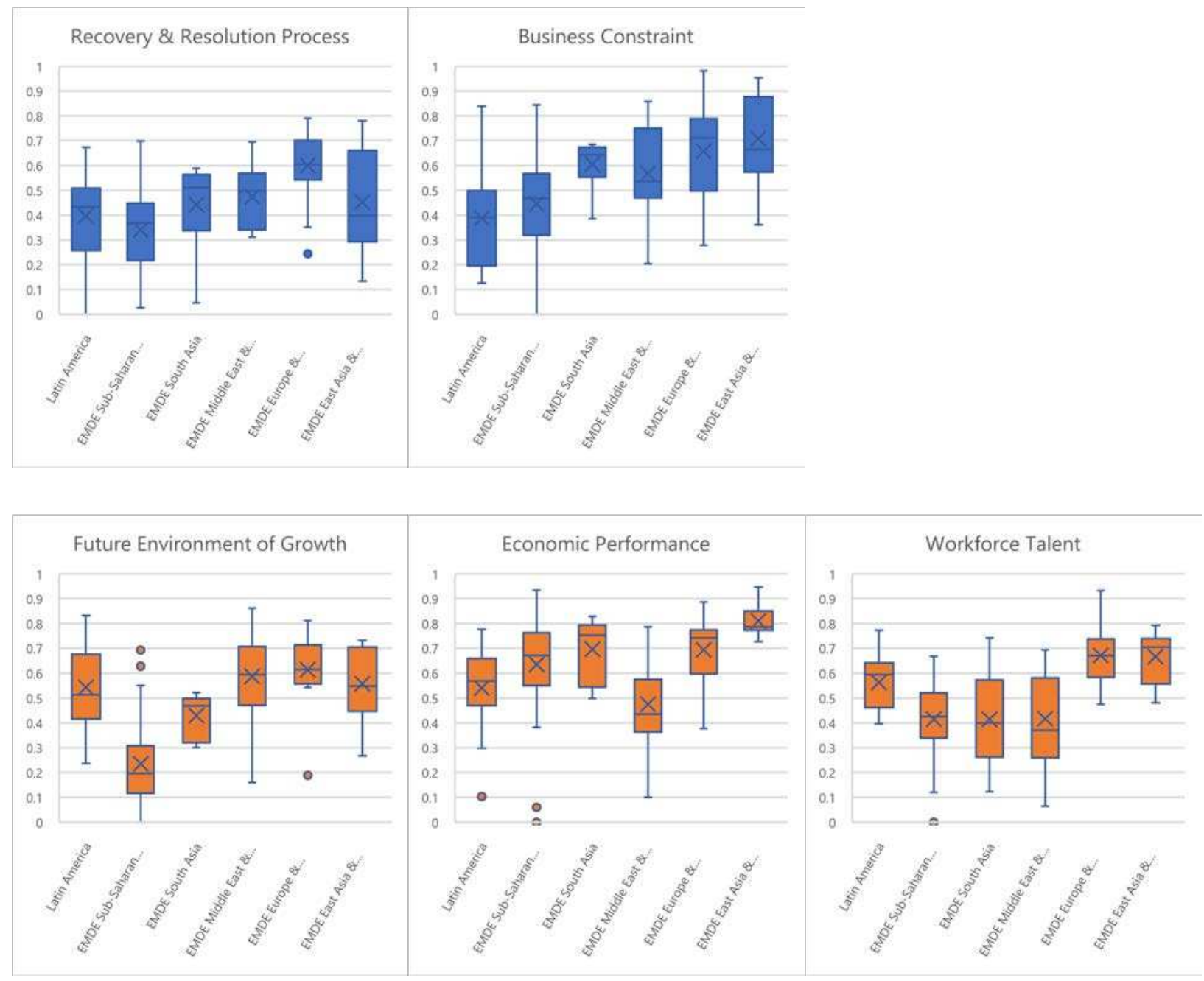

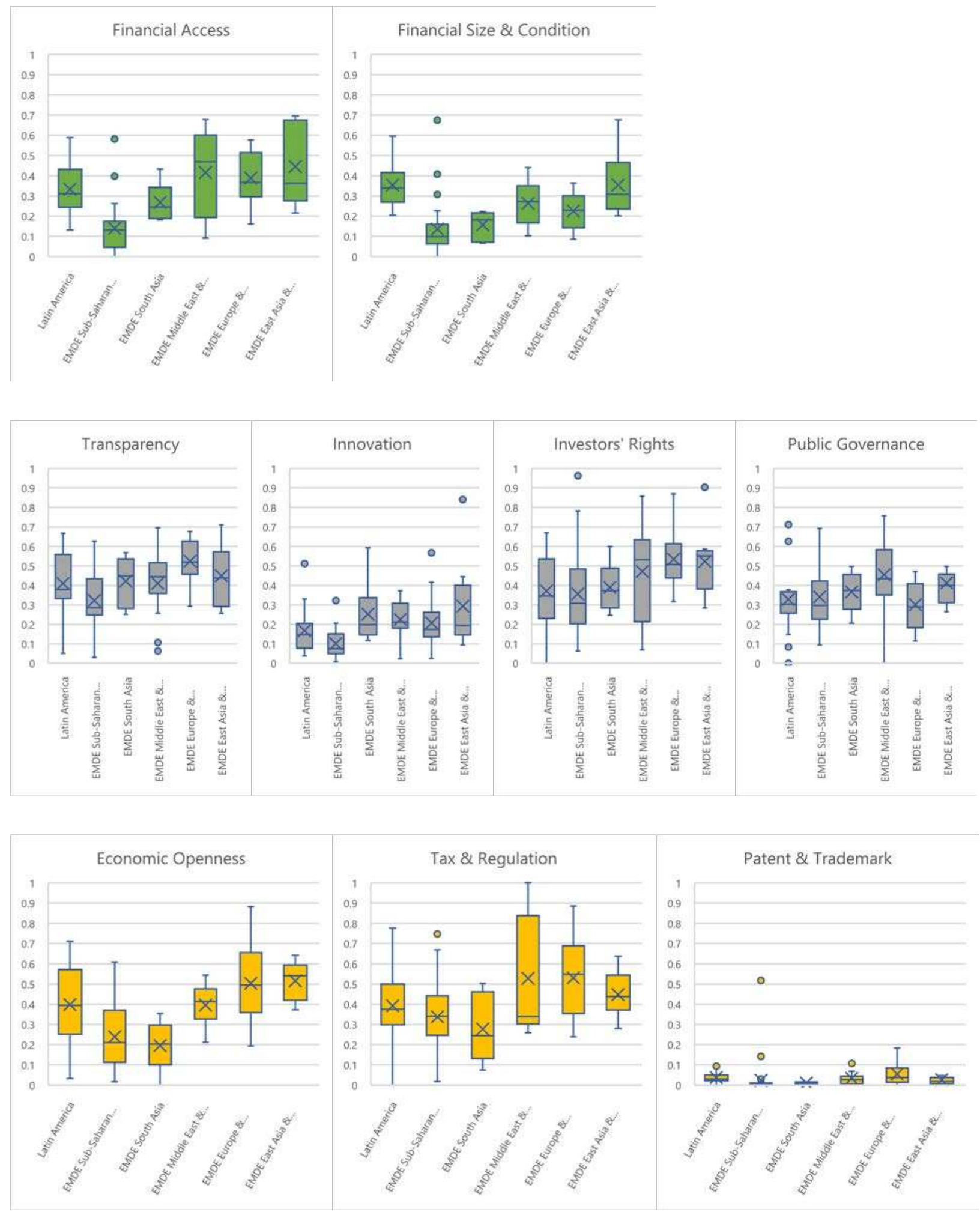

Note: Caribbean countries are not included as a regional grouping due to insufficient sample size.

Source: Authors' calculations based on Global Opportunity Index (2021) 
At the sub-category level, it becomes even clearer the specific areas where LATAM countries perform well and the areas to which countries in the region should improve upon to increase their overall attractiveness to foreign investors.

Business Constraint, a sub-category of Business Perception, shows LATAM countries performing worse than any other EMDE region. This sub-category captures the cost and effectiveness of starting a new business and the percentage of firms that identify corruption, labor regulations, and tax as an impediment to business.

Investors' Rights, a sub-category of Institutional Framework, is another weak point for LATAM countries. This reflects a lack of legitimacy in the rights afforded to investors and instability in government policymaking. This finding is intuitive given the number of investor-state disputes that have involved LATAM countries in recent years, with Mexico, Peru, and Colombia all facing three known disputes in 2019 - tied for the highest number of new disputes brought against a single country that year. ${ }^{3}$

The best sub-categories for LATAM countries are found in Economic Fundamentals and Financial Services. Workforce talent, a measure of the workforce's qualifications and diversity, is a strong point for the region and is a good sign for investors that prioritize highly skilled workers. Financial Size and Condition, a measure of the existing financial system's breadth and depth and a good indicator for future business activity, is the other region's top sub-category.

\section{Top-5 Economies in Latin America}

The remaining portion of this section will focus on the five largest economies in the LATAM region. ${ }^{4}$ As discussed in greater detail in Section 2, most foreign capital inflows to the region are concentrated among Argentina, Brazil, Chile, Colombia, and Mexico. Therefore, it is fair to assume that investors are particularly attentive to these five countries' performance in the Index.

As Figures $1.6 \& 1.7$ show below, Chile is the best performer among the region's largest economies with a strong performance across the five categories. Mexico is also fairly uniform in its performance, except for Financial Services, where it visibly underperforms. Colombia is slightly worse than Mexico, with suppressed scores in Business Perception and Financial Services.

Brazil and Argentina's performance reflects the approach towards attracting foreign investment that has often been associated with the LATAM region, highly skewed toward achieving macroeconomic stability.

\footnotetext{
${ }^{3}$ Investor-state disputes (also known as ISDS) involve a foreign investor initiating binding arbitration against the government of the country in which their investment is located. Disputes typically relate to either the alleged direct or indirect expropriation of an investor's investment by the host government. The provisions that make this possible are stipulated in the investment protection chapters of most international investment agreements. See UNCTAD (2020a).

${ }^{4}$ Economy size in Latin America is determined using GDP (current US\$) figures provided by the World Bank.
} 
Both countries perform well in Economic Fundamentals and, to a lesser extent, Financial Services. However, like the region as a whole, there is significant room for improvement in Business Perception and Institutional Framework, reflecting issues related to corruption, transparency, and reliable redress for grievances.

Collectively, Chile and Mexico model the performance that the other large economies in the region should endeavor to achieve-a near-uniform competency across all categories, as opposed to a strong performance in one and weakness in the others.

Figure 1.6: Performance of top-5 LATAM economies

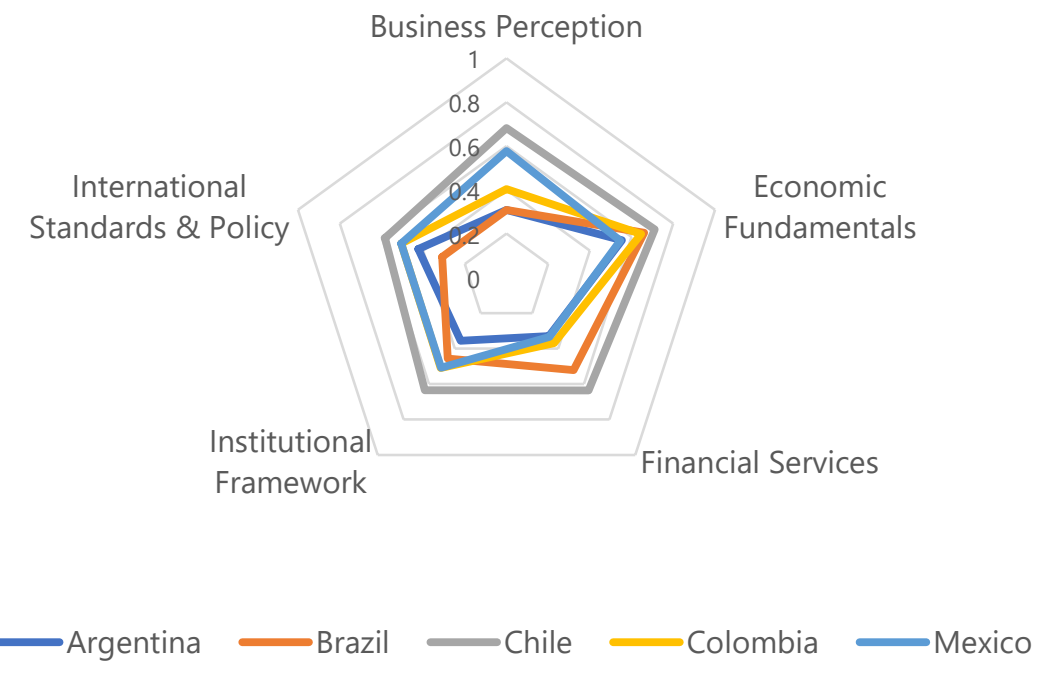

Source: Authors' calculations based on Global Opportunity Index (2021) 
Figure 1.7: Comparing top-5 LATAM economies with EMDE benchmark group

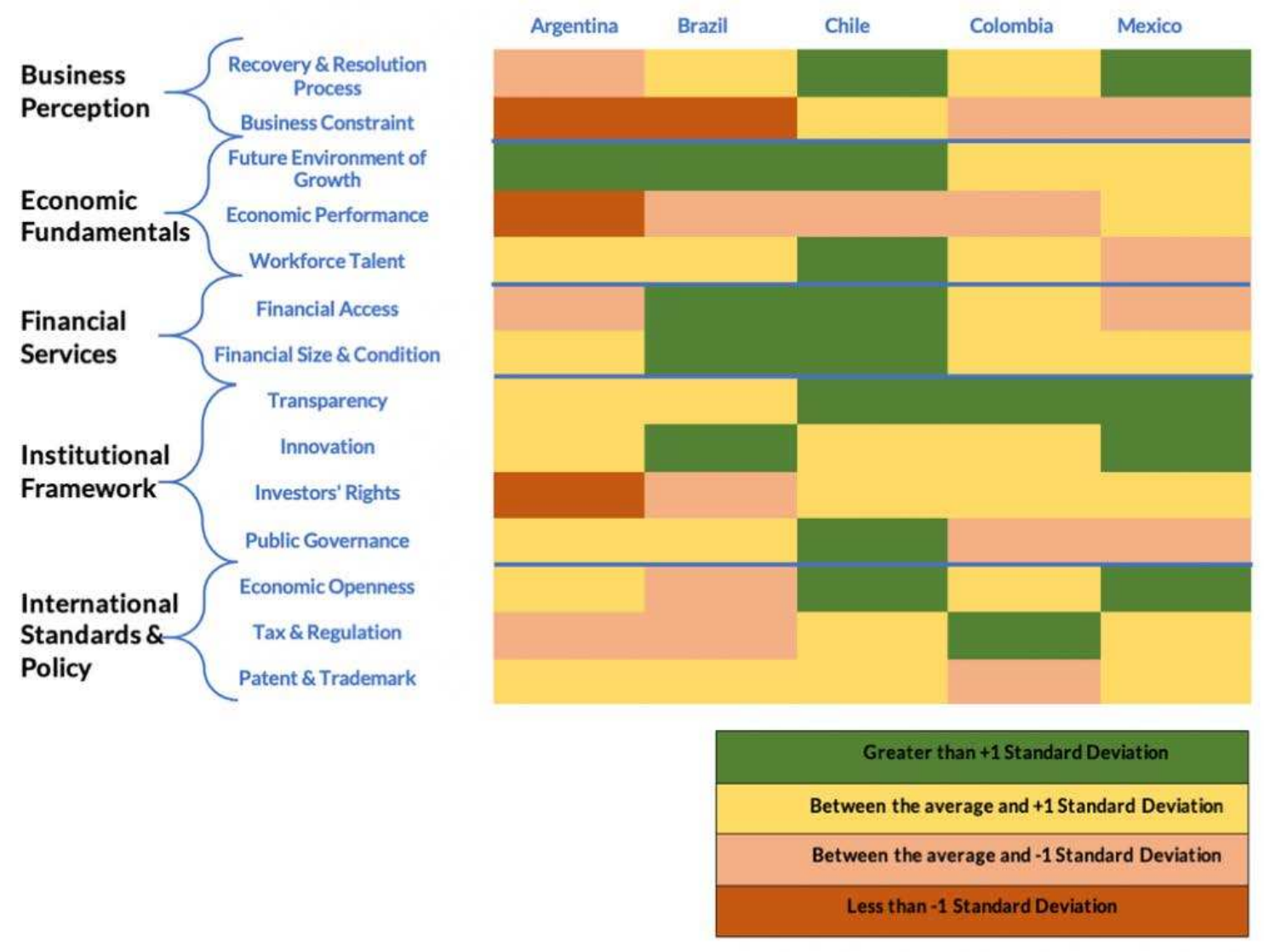

Note: Values are compared with the mean value of the 109 countries included in the EMDE benchmark group.

Source: Authors' calculations based on Global Opportunity Index (2021) 


\section{Section 2. Recent Trends in Private Cross-Border Capital Flows to Latin America}

Latin America has long received a relatively small fraction of global capital flows, and this fraction has further declined over the past decade (see figure 2.1). ${ }^{5}$ The share of international capital flows going to the region fell from about 7 percent in 2010-2014 to about 5 percent in 2015-2019. Furthermore, this decline was not due to an overall reduction in capital flows to emerging and developing economies (see figure 2.2). Over the same two periods, inflows to China increased from about 6 to 7 percent of total global flows, and inflows to other emerging and developing Asian markets increased from about 5 to 6 percent. Only emerging and developing Europe experienced a larger reduction than Latin America, with its share in global flows decreasing from about 4 percent during the 2010-2014 period to about 2 percent during 2015-2019.

\section{Figure 2.1. Private Cross-Border Capital Inflows to Latin America}

\section{(Percent)}

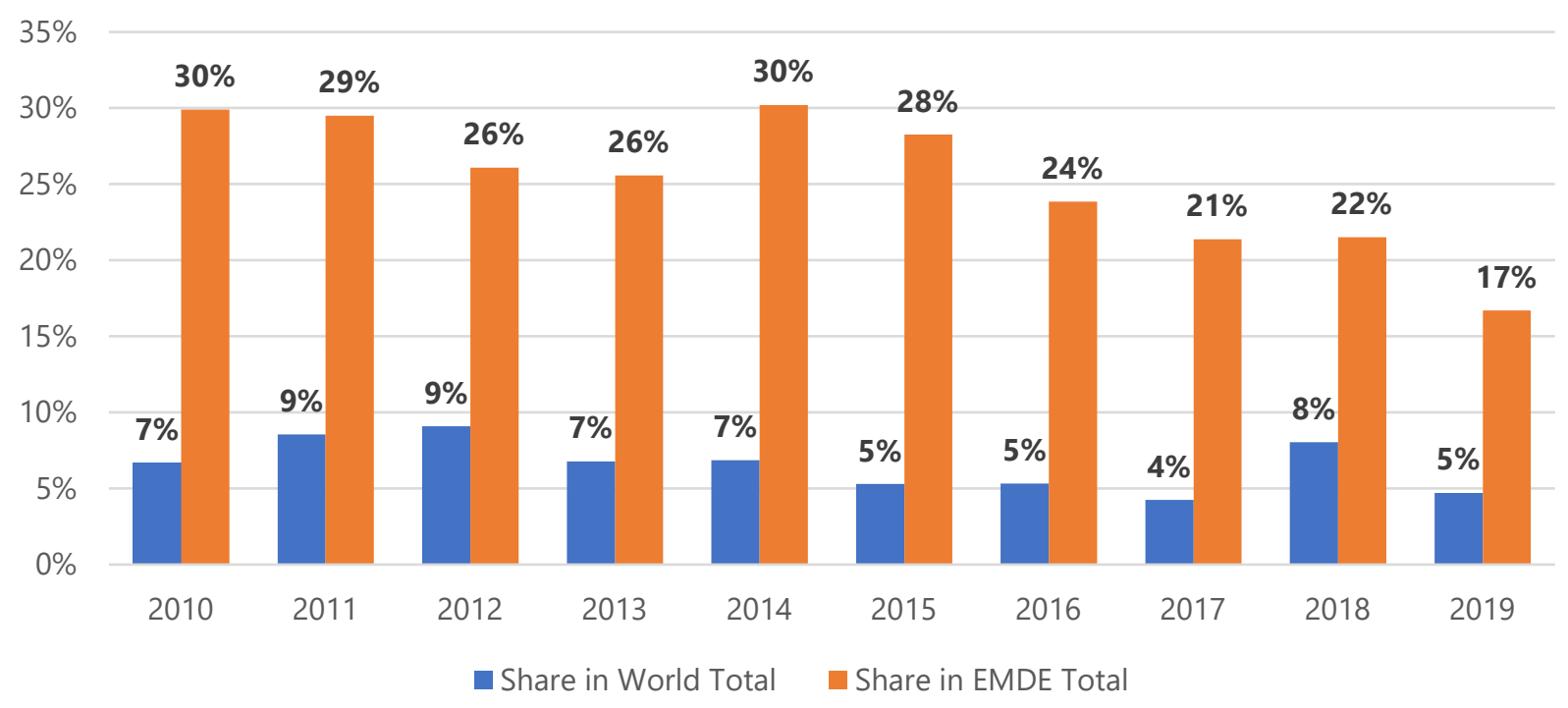

Note: See Appendix 1 for a full list of the economies included in the EMDE category.

Source: IMF International Financial Statistics; authors' calculations (2020)

This reversal in global capital inflows has affected Latin America's relative position among emerging markets and developing economies (EMDE). Between 2010 and 2014, the region attracted 28 percent of

\footnotetext{
${ }^{5}$ To capture foreign investors' attitude towards Latin America, we focus on "gross" inflows, defined as any change in external liabilities incurred by the recipient economy (see OCDE, 2018). These inflows can have a positive sign (when nonresidents purchase domestic assets) or a negative sign (when nonresidents sell their domestic assets). For the same reason, we also focus on "private" inflows and exclude some types of instruments that are largely affected by non-market factors. Hence, we exclude reserve asset accumulations and flows to the general government and monetary authorities within the "Other Investment" component of the financial account. We also exclude capital movements associated to financial derivatives, which represent a small fraction of total flows, and to offshore financial centers, which tend to be unrelated to domestic factors.
} 
total global flows directed to these economies, making Latin America the largest recipient among this group of countries. But that fraction decreased to about 22 percent during the 2015-2019 period, below that of China (30 percent) and other emerging and developing Asian economies (24 percent).

\section{Figure 2.2. Private Cross-Border Capital Inflows by Destination}

\section{Share in World Inflows}
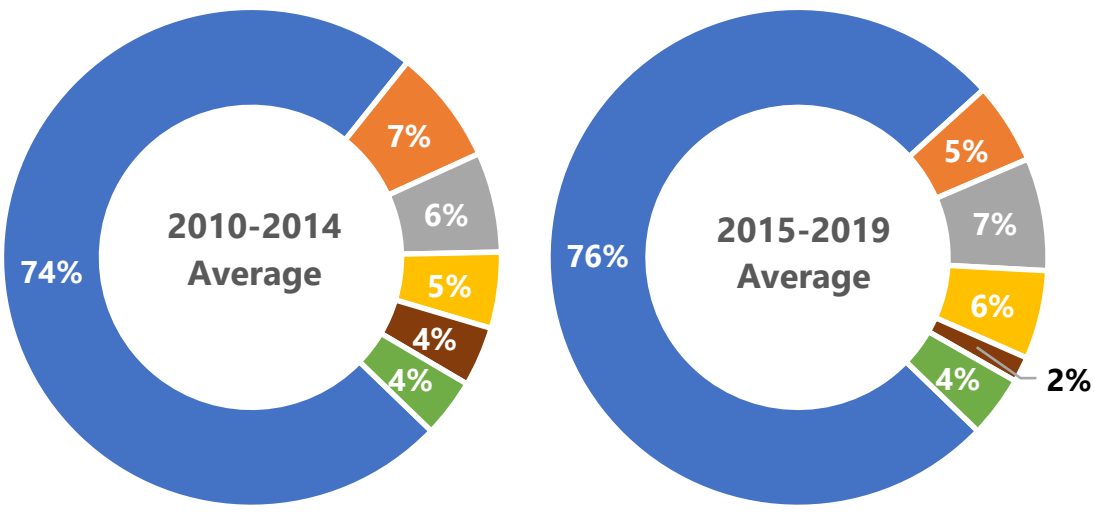

\footnotetext{
- Advanced Economies

- China

- EMDE Europe
}

$$
\begin{aligned}
& \text { - Latin America } \\
& \text { EMDE Asia (excl. China) } \\
& \text { - Rest of EMDE Economies }
\end{aligned}
$$




\section{Share in Emerging Market and Developing Economies Inflows}

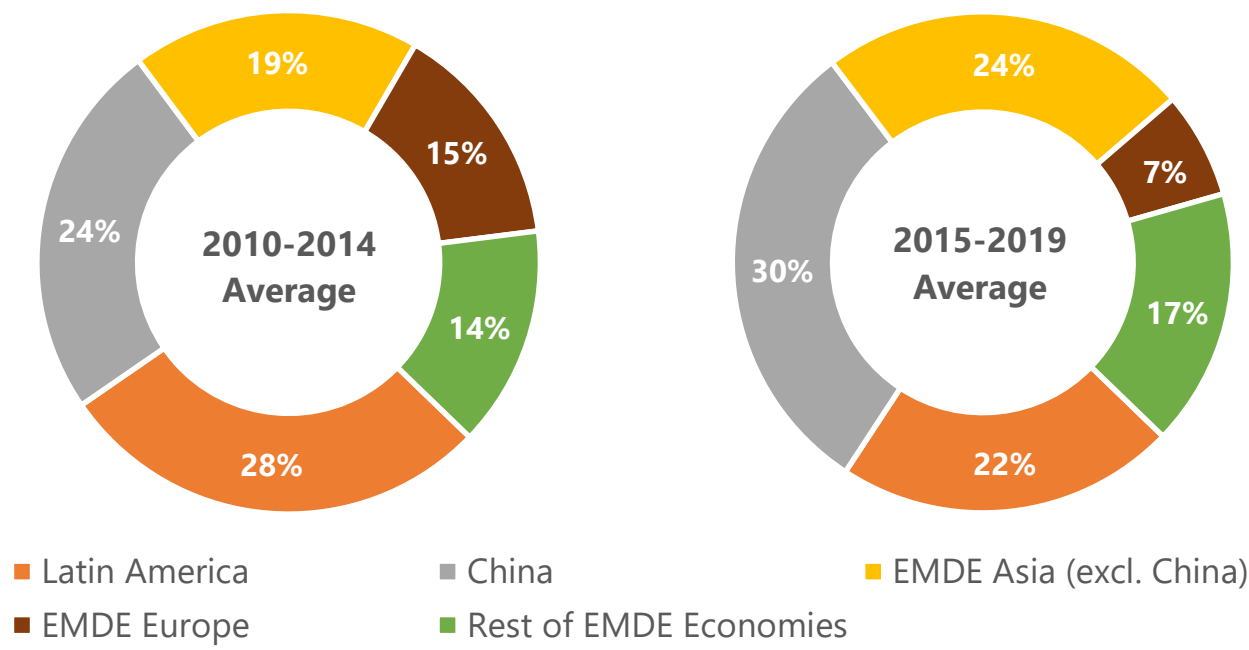

Note: See Appendix 1 for a full list of the economies included in each category.

Source: IMF International Financial Statistics; authors' calculations (2020)

\section{Components of Private Cross-Border Capital Inflows}

Figures 2.3 and 2.4 illustrate that while all four types of capital flows to Latin America decreased over the past decade, the decline was particularly large for bank-related and portfolio investment flows. During the 2015-2019 period, cross-border capital flows from banks and other private sources were 96 percent lower than during the previous five years. Between the same two periods, portfolio investment in debt decreased by 60 percent, and portfolio investment in equity decreased by 52 percent. By contrast, the decline in FDI inflows was relatively small—only about 14 percent. 
Figure 2.3. Private Cross-Border Capital Inflows to Latin America, by Component (US\$ Billions and percent of GDP)

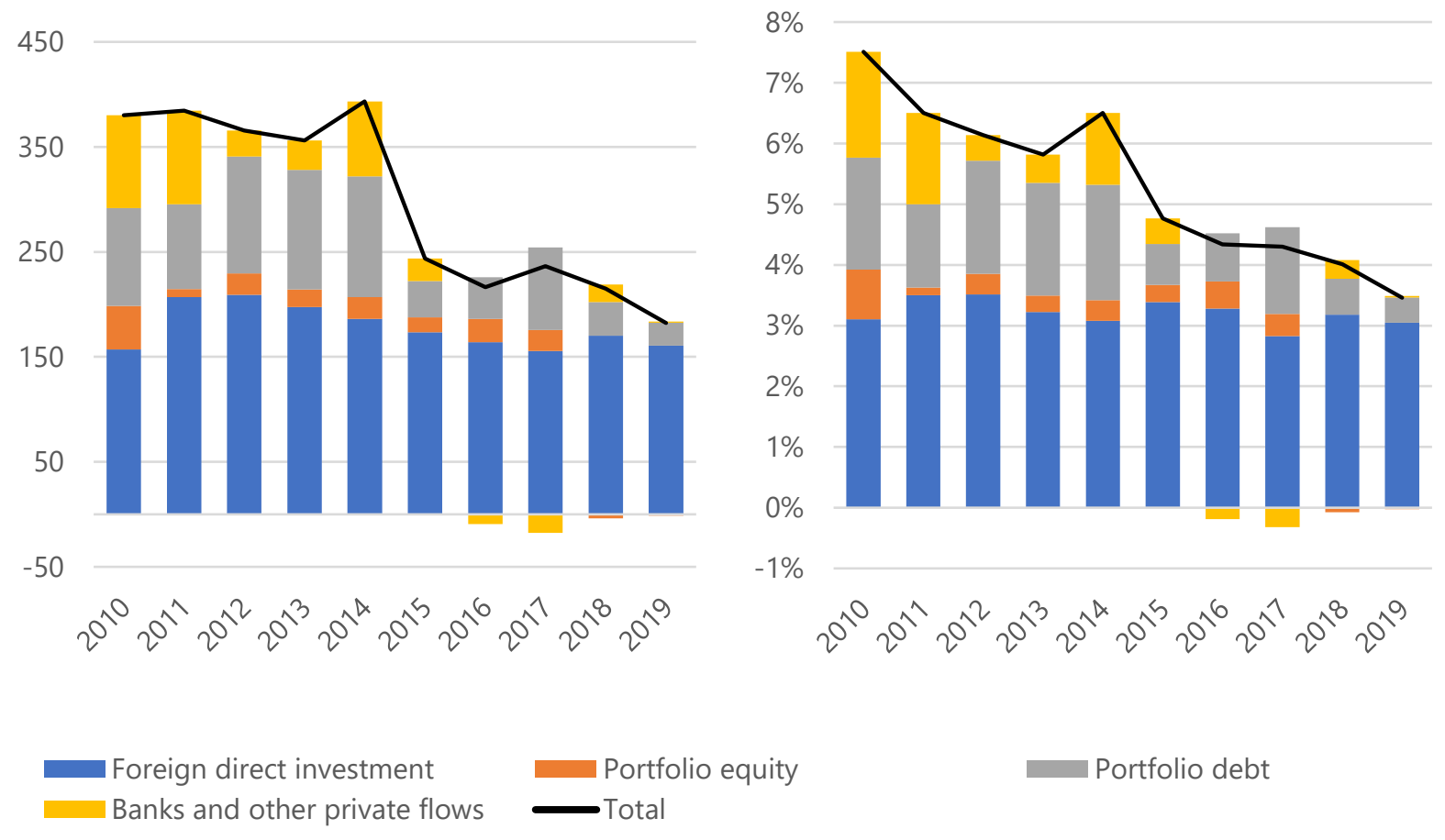

Source: IMF International Financial Statistics; authors' calculations (2020)

Furthermore, the figures also illustrate that different types of capital flows exhibit significantly different behavior in terms of volatility. This volatility has long been a concern for policymakers in Latin America, given the region's history of economic crises and sharp capital flow reversals. ${ }^{6}$ The figures show that FDI inflows are (by far) the least volatile component of capital flows, whereas bank-related and other private sources are clearly the most volatile. Portfolio investment inflows fall somewhere in between-and, within this category, portfolio debt tends to be more stable than portfolio equity. Although global conditions partly determine the volatility of capital flows, domestic policies can help reduce it-particularly those aimed at promoting macroeconomic soundness and strengthening local banking systems. ${ }^{7}$

\footnotetext{
${ }^{6}$ The recent history of cross-border capital flows to Latin America includes "the flood of dollars from newly rich Middle Eastern oil exporters, recycled as loans from U.S. and European banks, that washed over the region starting in the mid-1970s. Then came the Mexican debt default of 1982, which set off an economically devastating outflow of capital from the region that lasted for most of the 1980s. In the early 1990s the capital flows resumed, with portfolio and direct investment this time playing a bigger role than bank loans. The Mexican peso crisis of 1994 slowed this inflow, but unlike the debt crisis of the 1980s it hasn't stopped it." (Fox, 1998)

${ }^{7}$ For a discussion of discussion with Latin America's experience with global capital flows, see Edwards (1998).
} 
Figure 2.4. Composition of Private Cross-Border Capital Inflows to Latin America (US\$ Billions)

Total private inflows

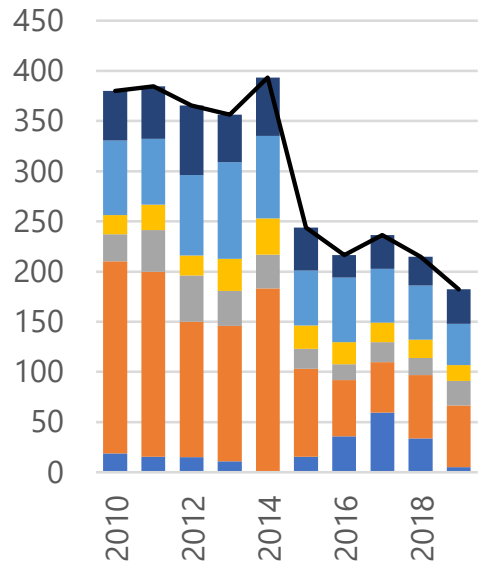

Portfolio debt

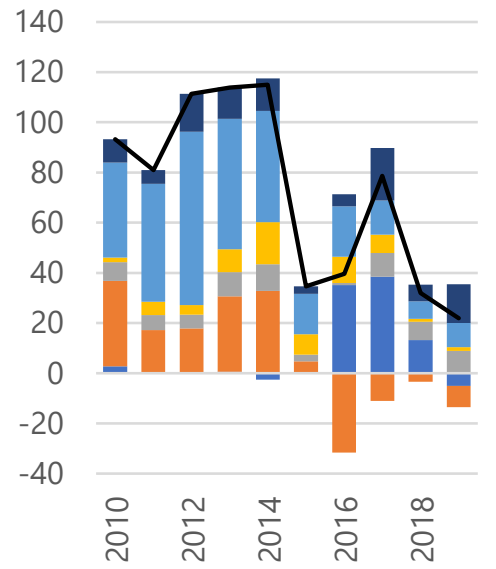

FDI

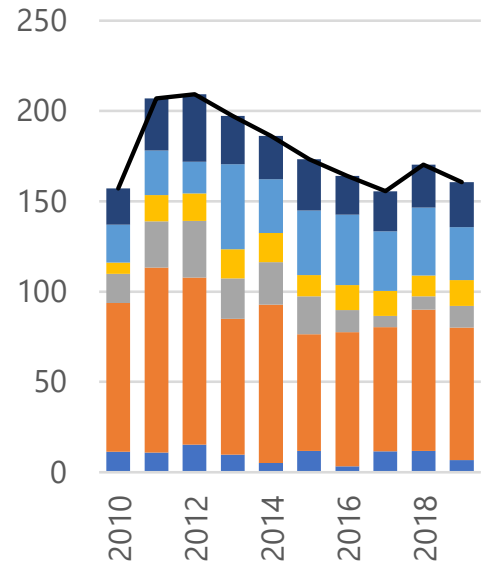

Banks and others flows

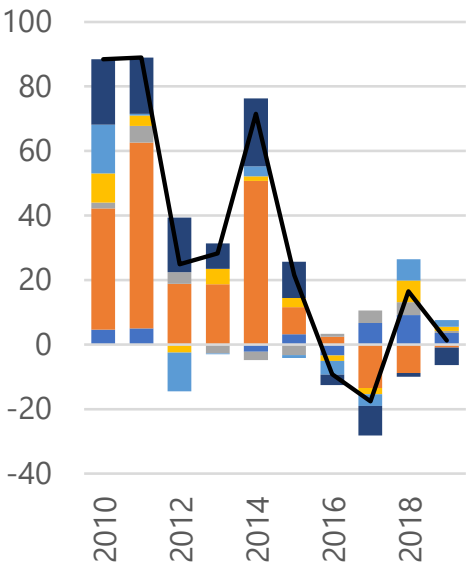

Argentina Brazil

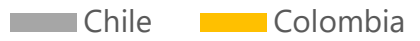

Mexico

Others Total

Source: IMF International Financial Statistics; authors' calculations (2020)

\section{Composition of Private Cross-Border Capital Inflows}

The recent evolution of the various types of cross-border capital flows to Latin America has led to a gradual shift in its overall composition (see figure 2.5). For instance, while initially a relatively important component, the significance of bank-related and other private sources declined considerably between 2015 and 2019. Over the same period, the relative importance of portfolio investment in debt also fell, but 
it remained the second most important component of total inflows. On the other hand, while the volume of portfolio investment in equity has always been relatively small, its overall significance sharply fell during 2018 and 2019. Finally, the decade witnessed a significant increase in the importance of foreign direct investment. The share of FDI in total private cross-border capital inflows to Latin America jumped from about 51 percent in the first part of the decade to just above 72 percent during the 2015-2019 period.

Figure 2.5. Importance of Various Types of Private Cross-Border Capital Inflows to Latin America

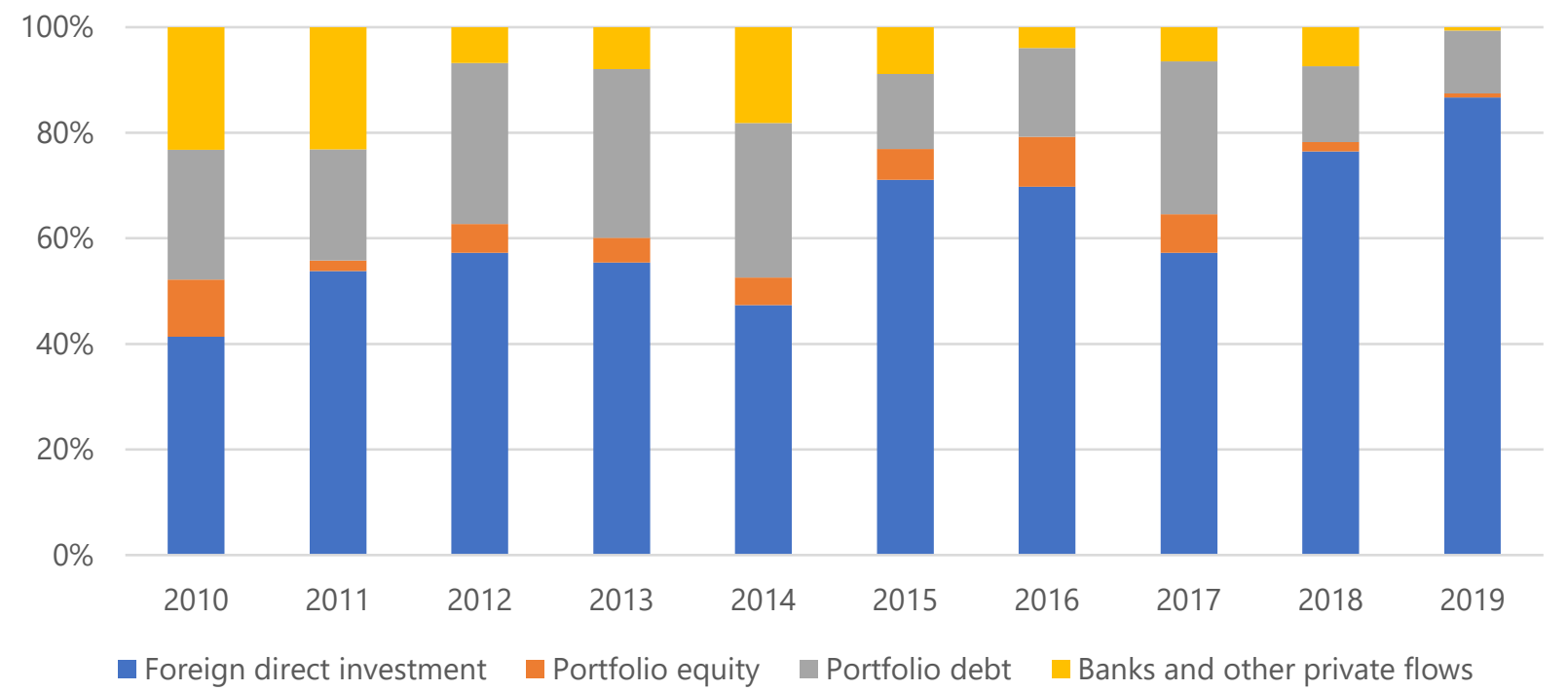

Note: The importance is calculated by dividing the absolute value of a given type of inflow by the sum of the absolute values of all kinds of flows.

Source: IMF International Financial Statistics; authors' calculations (2020)

\section{Heterogeneity in Private Cross-Border Capital Inflows}

Latin American countries are highly heterogeneous. They differ not only in their resource endowments, demographics, and overall levels of economic development, but they also have different political institutions, degrees of openness to international competition, and modes of insertion into the global economy. Perhaps unsurprisingly, each country's distinctive characteristics offer unique opportunities and challenges for foreign investors, thereby shaping capital inflows' magnitude and composition.

Figure 2.6 illustrates a critical aspect of the heterogeneity among Latin American countries: the unequal distribution of capital flows to the region. When viewed in absolute terms, most private cross-border capital flows to Latin America are concentrated in two economies: Brazil and Mexico. When combined, these two countries captured 65 percent of total capital flows during the 2010-2014 period and 53 percent during the 2015-2019 period. At a more granular level, Brazil and Mexico also received most of 
the FDI and portfolio equity flows to the region between 2010 and 2019 (with Brazil receiving a significantly higher share than Mexico in the first half, and Mexico receiving a higher percentage than Brazil in the second half).

Figure 2.6. Private Cross-Border Capital Inflows to Selected Latin American Countries (US\$ Billions)

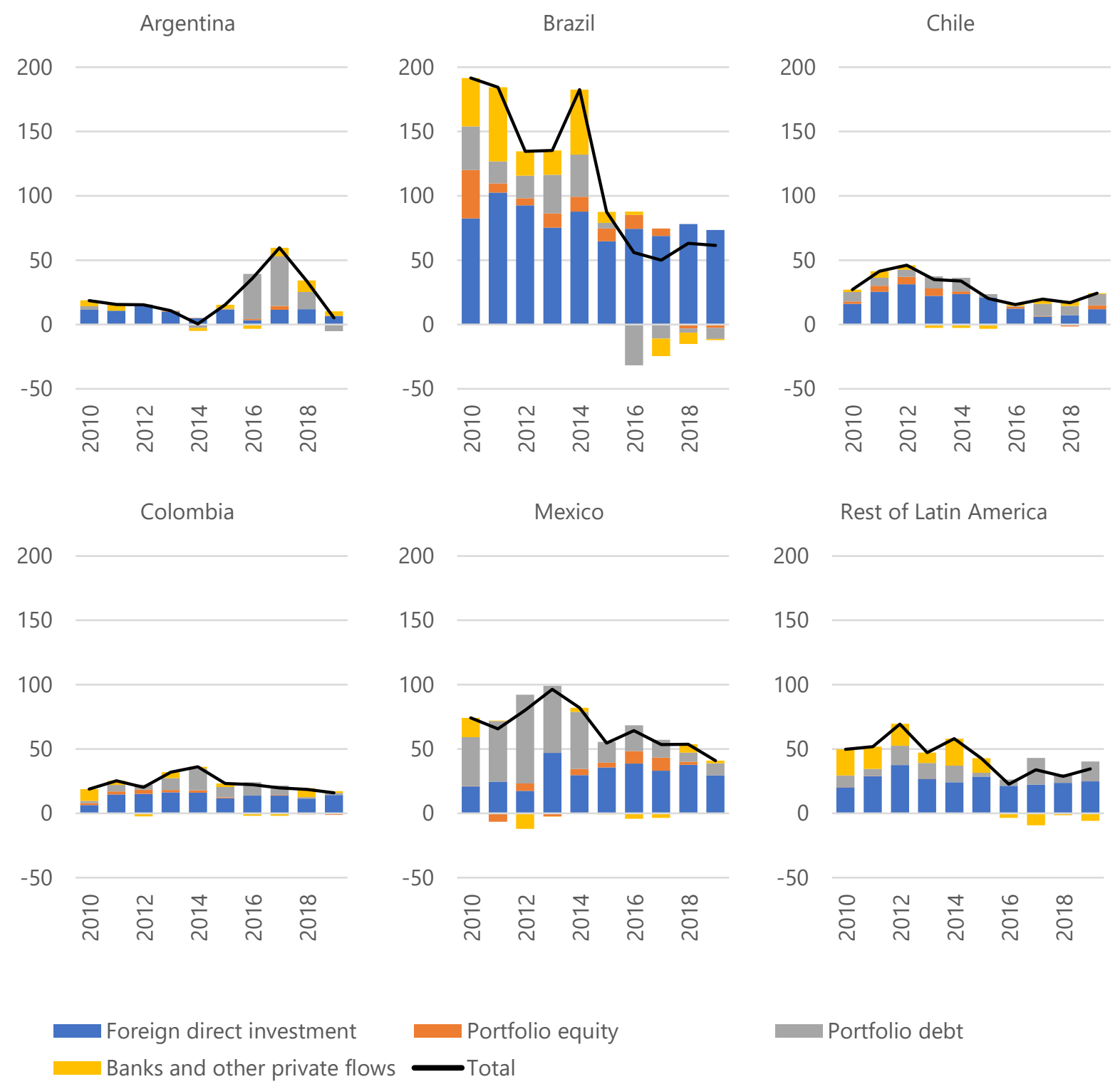

Source: IMF International Financial Statistics; authors' calculations (2020) 
Furthermore, the figure illustrates that, over the past decade, capital inflows have been significantly more volatile in Argentina and Brazil than in the rest of Latin America. This volatility has been primarily driven by the behavior of portfolio investment in debt and bank-related inflows, and it can be partially explained by the economic challenges faced by these two countries in the mid and late 2010s. These challenges included Argentina's debt default in 2014 and economic crisis in 2018, as well as Brazil's severe economic recession in mid-2014-a product of the sharp decline in commodity prices and a series of internal political events that severely undermined investors' confidence.

\section{Figure 2.7. Importance of Selected Countries in Private Cross-Border Capital Inflows to Latin}

\section{America}

2010-2014

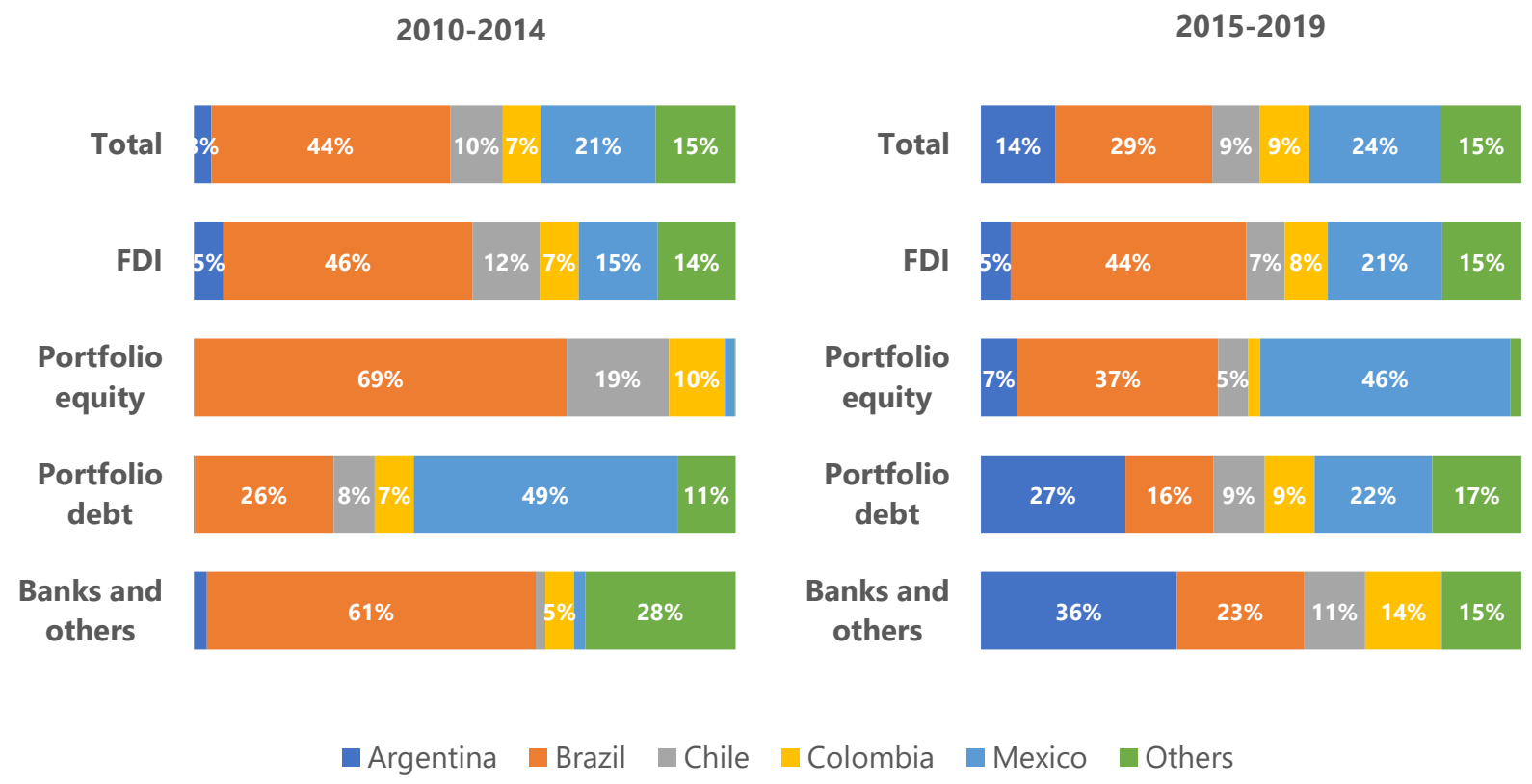

2015-2019

Note: The importance is calculated by dividing the absolute value of the inflows to a given country by the sum of the absolute values of the inflows to all the countries in the region.

Source: IMF International Financial Statistics; authors' calculations (2020)

Figure 2.7, on the other hand, shows that the distribution of flows has become more equal over time, particularly across portfolio investment (both in debt and equity) and bank-related flows. This change coincided with an increase in the relative importance of Argentina, particularly in portfolio investment in debt-from practically zero in 2010-2014 to about 27 percent in 2015-2019 — and bank-related and other private flows-from less than 2 percent in 2010-2014 to about 36 percent in 2015-2019.

From a country's perspective, however, what matters is the magnitude of inflows relative to the economy's size. When viewed as a percentage of GDP, private cross-border capital inflows were significantly higher in Chile than in the rest of Latin America, with an annual average of just below 11 percent between 2010 and 2019 (see figure 2.8). Colombia follows in a relatively distant second place, with a yearly average of about 
7 percent over the same period. Mexico and Brazil are in third and fourth places with 5.6 percent and 5.1 percent, respectively. Finally, among the five largest economies of the region, Argentina exhibits the lowest capital inflows as a fraction of GDP, with an annual average of just below 4 percent over the 20102019 period.

Figures 2.6 and 2.8 also illustrate that the decline in capital flows to Latin America during the 2010 s was a widespread phenomenon and not driven by a single country. Indeed, capital flows decline in most of the region's economies, both in absolute terms and as a fraction of GDP. For example, as a fraction of GDP, and relative to the 2010-2014 period, capital flows during 2015-2019 were about 50 percent lower in Brazil and Chile, 13 percent lower in Colombia, 31 percent lower in Mexico, and 43 percent lower in the rest of the region. Among the region's largest economies, Argentina was the only country that did not experience an overall decline in capital flows over the last decade. In fact, capital flows to Argentina during the 2015-2019 period were about 120 percent higher than during 2010-2014. 
Figure 2.8. Private Cross-Border Capital Inflows to Selected Latin American Countries (Percent of GDP)

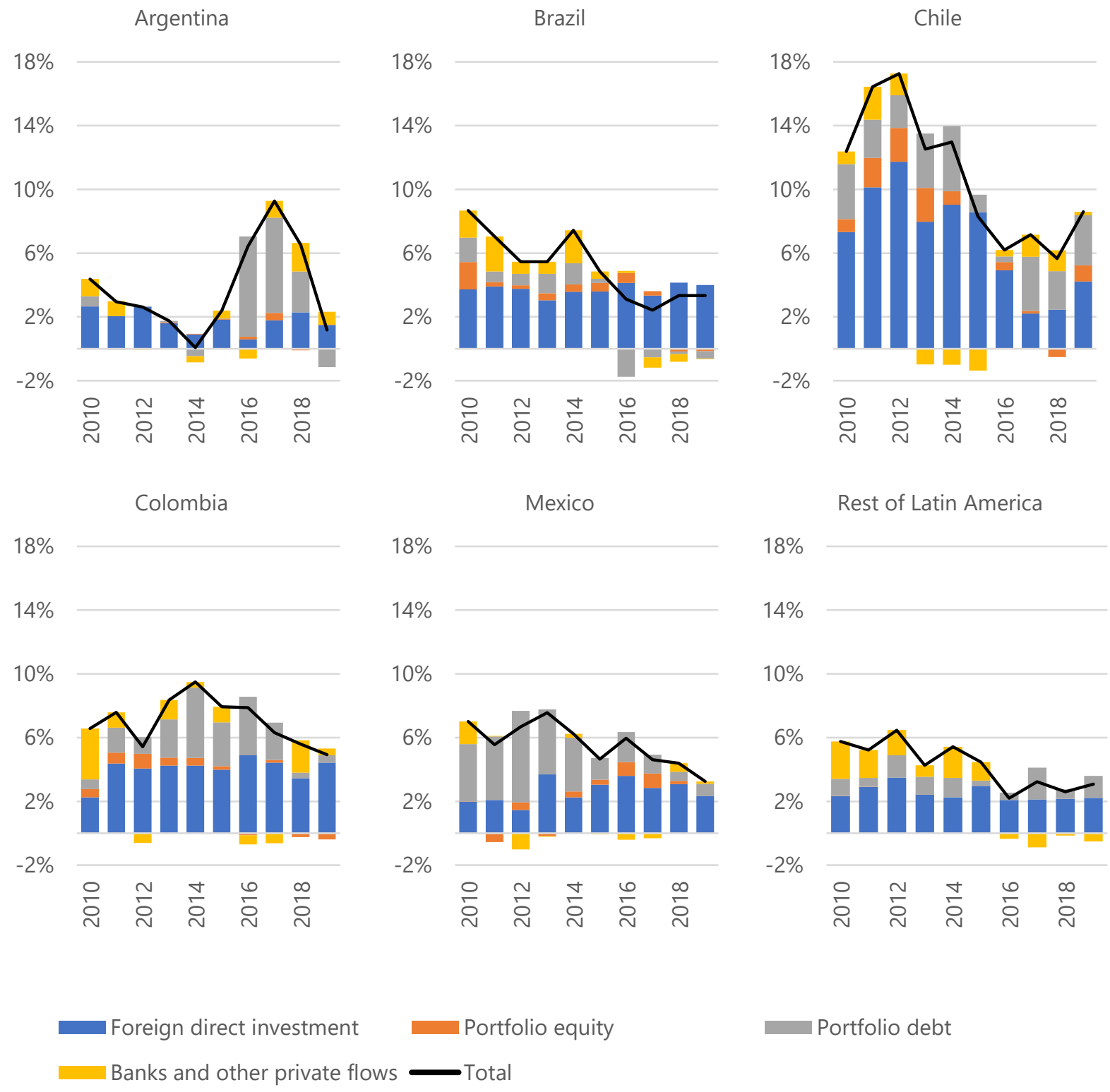

Source: IMF International Financial Statistics; authors' calculations (2020)

However, Argentina's unique behavior must be understood within the broader context of its often tumultuous economic and political history. Following a sharp decline between 2010 and 2014-a result of the country's multiple economic challenges that culminated in the 2014 government's default-global capital flows rose rapidly during the 2014-2017 period-after the election of President Macri in 2015 and 
the country's return to international capital markets. But the recovery was mostly driven by portfolio investment in debt and (to a lesser extent) bank-related inflows, both highly volatile and for the most part related to a surge in public debt. In late 2017, the economy began to deteriorate, and capital flows once again declined, only to plunge in 2019 after the presidential election-where President Macri lost to the Peronist ticket, whose campaign was primarily based on a reorientation of the country's economic policies. $^{8}$

Figure 2.9. Importance of Various Types of Private Cross-Border Capital Inflows to Selected Latin American Countries

2010-2014

$$
\text { Argentina }
$$

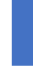

Colombia

Mexico

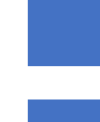

$$
52 \%
$$$$
8 \%
$$$$
35 \%
$$$$
53 \%
$$$$
86 \%
$$$$
\begin{array}{l|l|l}
9 \% & 16 \% & 22 \%
\end{array}
$$$$
65 \%
$$$$
11 \% \quad 21 \%
$$$$
\begin{array}{ll}
28 \% & 12 \%
\end{array}
$$$$
63 \%
$$$$
20 \%
$$$$
30 \%
$$

\section{$\mathbf{5 0} \%$}

$20 \%$

Foreign Direct Investment
2015-2019

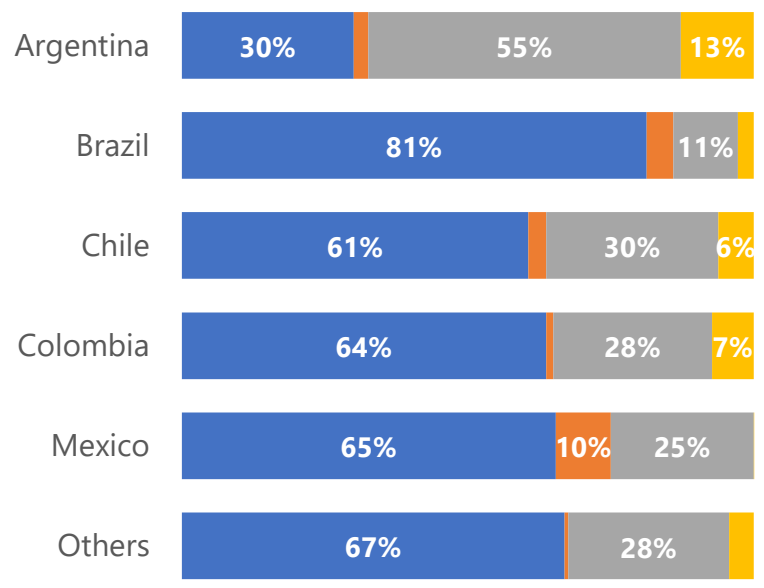

Portfolio debt

Note: The importance is calculated by dividing the absolute value of a given type of inflow by the sum of the absolute values of all kinds of flows.

Source: IMF International Financial Statistics; authors' calculations (2020)

\section{Heterogeneity in the Composition of Capital Inflows}

The composition of capital flows also varies across countries and over time within a given country. Figure 2.9 illustrates this heterogeneity, showing the relative importance of the various types of private crossborder capital inflows to the five largest Latin American economies and the rest of the region. On average, between 2015 and 2019, foreign direct investment and portfolio debt inflows have been the most important components of capital flows for all economies. However, there are marked differences across countries. For instance, FDI flows are unusually large in Brazil (81 percent), and portfolio debt flows are unusually large in Argentina (55 percent). In Mexico, bank-related inflows have been insignificant over the

\footnotetext{
${ }^{8}$ For a brief review of Argentina's recent economic challenges, see Nelson (2020).
} 
2010-2019 period, primarily due to its macroprudential regulation. Finally, the importance of portfolio equity flows has decreased in Brazil, Chile, and Colombia, but it has increased in Mexico and, to a lesser extent, Argentina.

\section{Foreign Direct Investment: A Closer Look}

Foreign direct investment is by far the largest source of private capital inflows to Latin America. On average, between 2015 and 2019, FDI accounted for more than 70 percent of all private cross-border capital flows into the region. It is also one of the more stable flows and, according to a growing consensus, one that can provide significant benefits for the host economies. A recent article by the World Bank, for example, indicates that "FDI can accelerate the "catching up" process of developing economies and facilitate their integration within regional and global value chains." ${ }^{9}$

FDI inflows can be classified into three main categories. The first category is equity finance, in which foreign investors acquire already-existing companies ( $M \& A)$ or establish new ones (greenfield projects). The second is the reinvestment of earning, which refers to earnings of firms owned by foreign investors not remitted to the parent company. Finally, the third category is intercompany loans, which consist of loans extended by foreign parent companies or affiliated enterprises.

\section{Figure 2.10. FDI Inflows to Latin America and Selected Countries, by Component, 2010-2019} Average

(Percent)

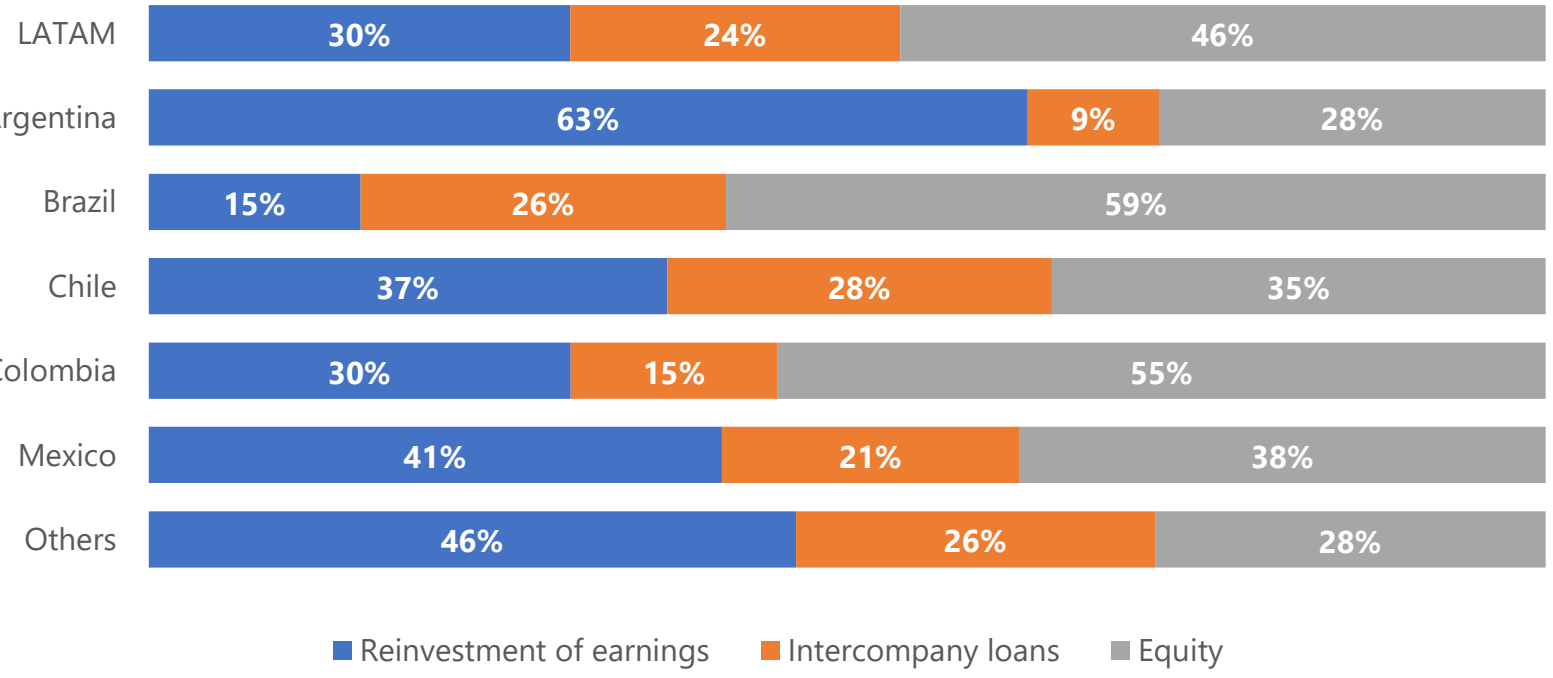

Source: IMF International Financial Statistics; authors' calculations (2020)

\footnotetext{
${ }^{9}$ Fruman and Forneris (2016).
} 
Most FDI inflows to Latin America take the form of equity capital. On average, between 2010 and 2019, this type of flow accounted for about 46 percent of the region's FDI flows (see figure 2.10). The relative importance of equity flows, however, varies significantly across countries. For instance, over the same period, the share of equity flows in total FDI was unusually large in Brazil (59 percent) and Colombia (55 percent). In contrast, it was relatively small in Argentina (28 percent). Chile and Mexico fell somewhere in between with 35 percent and 38 percent, respectively. The overall importance of equity capital flows is a good signal for Latin America. This type of flow is usually the strongest indicator of long-term interest among foreign investors.

FDI can also take the form of reinvestment of earnings, reflecting the confidence of foreign investors who have already set up their operations or have acquired businesses in the region. This type of FDI is vital in Latin America, accounting for about 30 percent of all FDI inflows between 2010 and 2019 (see figure 2.10). The relevance of reinvested earnings, however, varies significantly across countries. For some of the major economies in the region, such as Chile, Colombia, and Mexico, reinvested earnings accounted for more than 30 percent of total FDI inflows between 2010 and 2019; for Argentina, they made up an even larger fraction (about 60 percent). In contrast, over the same period, reinvested earnings accounted for only about 15 percent of Brazil's total FDI inflows. For the rest of the region, this type of investment is also significant, accounting for about 46 percent of all foreign direct investment.

The relevance of reinvested earnings in Latin America has an important implication for the short-term behavior of FDI inflows: the impact of the COVID-19 pandemic on foreign direct investment inflows to the region is likely to be severe. The current global crisis is expected to substantially lower the earnings of foreign affiliates based in Latin America, and investors are expected to reinvest a smaller share of these earnings than they have done in the past. Accordingly, FDI inflows to the region will likely drop substantially in the short term. ${ }^{10}$

Finally, between 2010 and 2019, intercompany loans accounted for almost one-fourth of total FDI inflows to the region. At a more granular level, and over the same period, this type of flow accounted for about 9 percent of total FDI inflows to Argentina, 26 percent to Brazil, 28 percent to Chile, 15 percent to Colombia, 21 percent to Mexico, and 26 percent to the rest of the region.

Intercompany loans are challenging to interpret, as their intentions and consequences are usually unclear, and they are often simply used for tax-planning purposes. However, some studies have shown that parent companies tend to use intercompany loans to support their foreign affiliates during challenging times. If that happens in the current situation, a rise in intercompany loans could partially offset a decline in reinvested earnings and equity flows. ${ }^{11}$

\footnotetext{
${ }^{10}$ See OECD (2020) and UNCTAD (2020b).

${ }^{11}$ See Desai, Fritz Foley, and Forbes (2008), and Alfaro and Chen (2012).
} 


\section{Origin of Foreign Direct Investment}

The origin of foreign direct investment inflows to Latin America has remained relatively stable between 2010 and 2018 (see figure 2.11). Most of the FDI flowing into the region came from the United States and Europe, with the former having a stronger presence in Mexico and the latter in South America (particularly in Argentina and Brazil). This pattern is in line with the strength of the commercial and historical ties between Mexico and the United States, on the one hand, and between South America and Europe, on the other.

Figure 2.11. FDI Inflows to Selected Latin American Countries, by Origin (Percent)

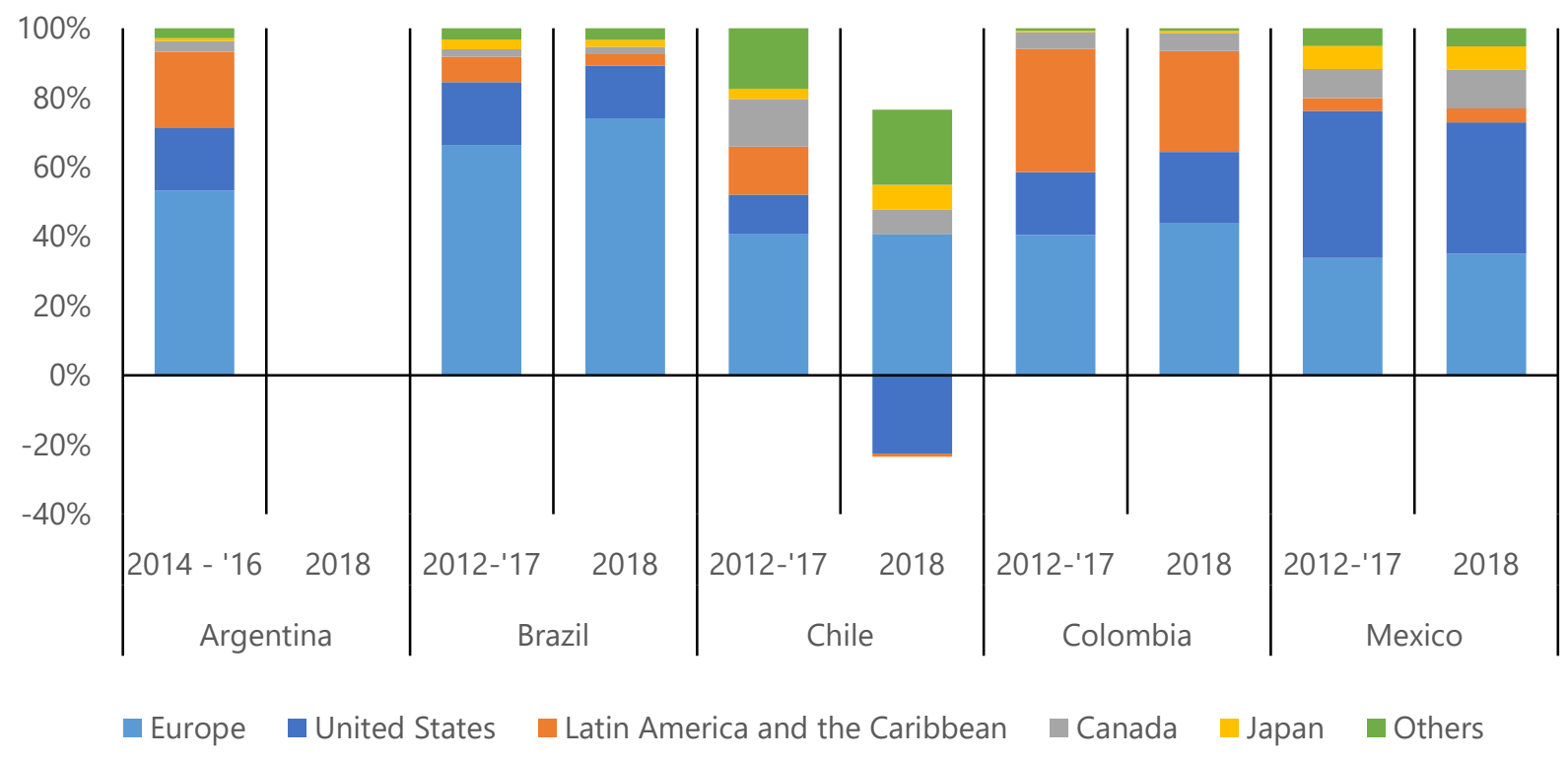

Source: Central Bank of Argentina, Central Bank of Chile, and Economic Commission for Latin America and the Caribbean (2020)

The importance of other sources varies by country. Inflows from other Latin American economies, for instance, have been particularly significant in Argentina and Colombia, surpassing even those from the United States. In Argentina, inflows from other Latin American economies accounted for 22 percent of total FDI inflows between 2014 and 2016; in Colombia, they accounted for 35 percent in 2012-2017 and 29 percent in 2018. On the other hand, Canada has a significant presence in Mexico (presumably because of NAFTA) and Chile (given Chile's rich copper and lithium deposits and the predominance of Canadian mining companies).

\section{FDI by Sector}


The services and manufacturing sectors are the two primary recipients of foreign direct investment in Latin America (see figure 2.12). On average, between 2014 and 2018, about 43 percent of total FDI flows to the region were directed to services, 41 percent to manufacturing, 13 percent to natural resources, and about $2 \%$ to other sectors (mostly mining). This outcome is not surprising, as manufacturing and services already captured most foreign investment between 2010 and 2014. The novelty is the significant reduction in the natural sector, which during the 2010-2014 period accounted for about 22 percent of the total FDI inflows. This reduction was primarily driven by the relative worsening in commodity prices during the second half of the 2010s, indicating that the decline is likely to persist until global economic conditions improve.

\section{Figure 2.12. FDI Inflows to Latin America and Selected Countries, by Sector}

(Percent)

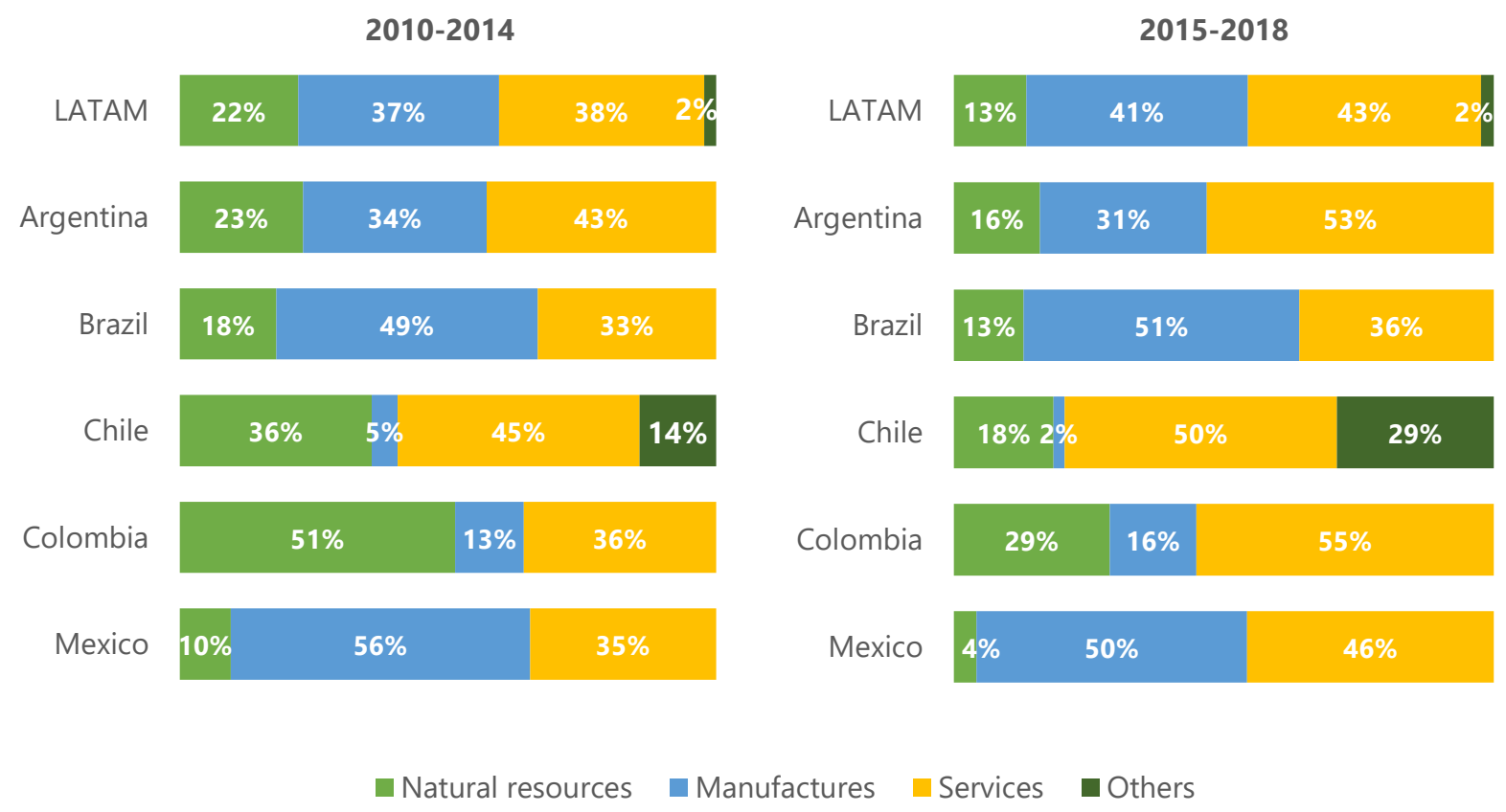

Note: Due to data limitations, Latin America's calculations exclude Guyana, Peru, Suriname, and Venezuela.

Source: Economic Commission for Latin America and the Caribbean (2020)

Finally, figure 2.12 illustrates that aggregate data hide key differences in the sectoral allocation of FDI at the country level. Inflows into the natural resources sector, for example, are unusually large in Colombiawhere they represented 29 percent of total FDI inflows between 2015 and 2019-but relatively insignificant in Mexico-where they accounted for only about 4 percent of the total. There are also wide variations across countries in the share of FDI going into manufacturing between 2015 and 2019, ranging from 51 percent in Brazil and 50 percent in Mexico to 16 percent in Colombia and 2 percent in Chile. 
Furthermore, inflows to other sectors (mostly mining) are significant only in Chile, accounting for about 29 percent of total FDI.

\section{Section 3. Cross-Border Mergers and Acquisitions in Latin America}

Cross-border mergers and acquisitions (M\&A) are an important component of Latin America's FDI, and most of the region's activity is dominated by the five largest economies by GDP. Fro the period 2010 to 2020, Brazil attracts the most M\&A, both in number of transactions and on an aggregate deal volume level (\$US Billions), followed by Mexico and Chile. (see figure 3.1). It should be mentioned that Mexico regulates foreign ownership for some key sectors, impacting the number of deals (see table 3.1).

\section{Figure 3.1. M\&A Activity in Latin America, Target Nations}

\section{a. All M\&A Activity in Latin America, Target Nations}

Number of Transactions

US\$ Billion

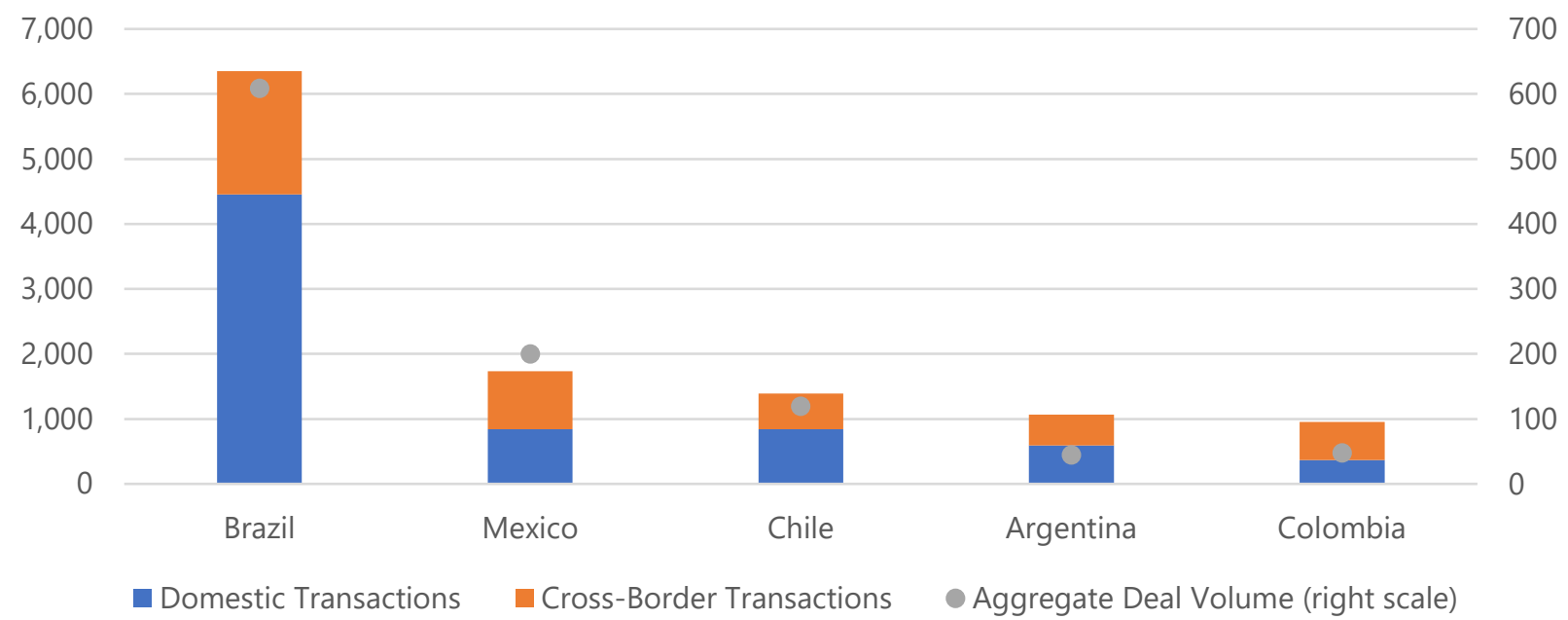




\section{b. Cross-Border M\&A Activity}

Number of Transactions

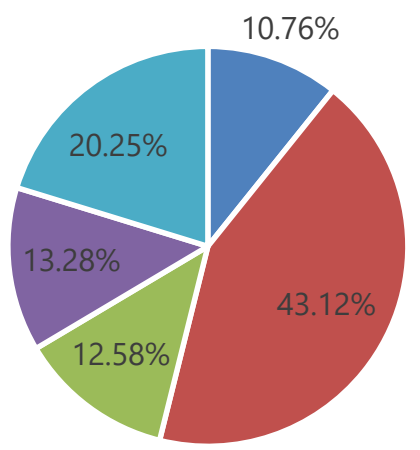

- Argentina - Brazil $=$ Chile - Colombia - Mexico

Source: EIKON (11.16.2020) and World Bank (2020); authors' calculations
Deal Volume

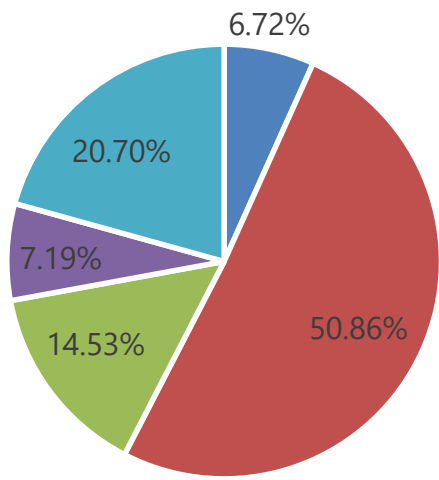

- Argentina - Brazil $\|$ Chile - Colombia - Mexico

Table 3.1: Foreign Ownership of Mexican Companies

\begin{tabular}{|l|l|l|}
\hline $\begin{array}{l}\text { Reserved for Mexican } \\
\text { State }\end{array}$ & $\begin{array}{l}\text { Reserved for Mexican } \\
\text { Corporations }\end{array}$ & Foreign Investment $49 \%$ \\
\hline $\begin{array}{l}\text { Oil \& Gas } \\
\text { Public Utilities }\end{array}$ & $\begin{array}{l}\text { Tourism } \\
\text { Banking }\end{array}$ & $\begin{array}{l}\text { Arms, Explosives, Ammo } \\
\text { Printed News }\end{array}$ \\
\hline Nuclear Power & Cargo & $\begin{array}{l}\text { Agriculture, Livestock, Forestry, } \\
\text { Fishing }\end{array}$ \\
\hline Telegraph and Radio & & Shipping (ex. Tourism) \\
\hline Postal Services & & Broadcasting \\
\hline Ports & & \\
\hline
\end{tabular}

Source: MexLaw - International Standards (2020)

The weaker M\&A activity in Argentina (relative to the country's GDP) may be partially related to its bankruptcy laws. Argentina does not have 'debtor-in-possession' financing protection for insolvent companies. The declaration of bankruptcy brings about two major consequences. First, the debtor loses possession and management over its assets. Second, a trustee assumes the debtor's assets and businesses' administration. In most cases, this leads to an immediate liquidation of the entity, without a chance for turnaround, creating uncertainty and instability in industries that are not inherently cash flow safe. 
Figure 3.2. Country Risk Premiums

(Percent)

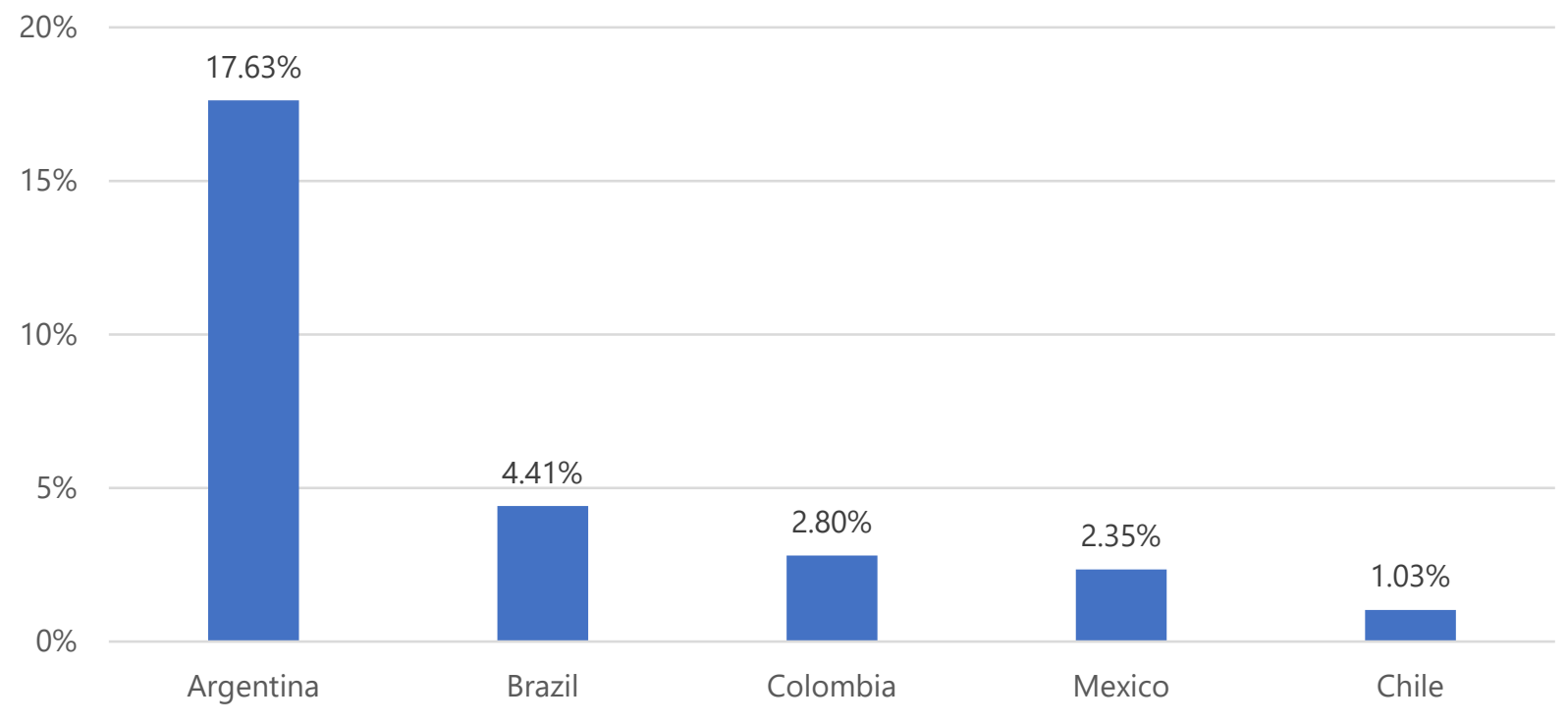

Source: Aswath Damodaran (2020)

Exacerbating the previous issue is the relative insolvency of the Argentinian government, which can significantly affect M\&A activity through the Country Risk Premium (CRP). ${ }^{12}$ The Country Risk Premium is the additional return demanded by investors to compensate them for the higher risk inherent in foreign countries. The CRP can significantly impact valuation calculations (and therefore investment decisions) and is affected by several factors such as political instability, economic risks (inflation), sovereign debt burden, sovereign debt default probability, and adverse government regulations (bankruptcy law, expropriation, currency controls).

Figure 3.2 depicts the most recent country risk premium for the five largest Latin American economies. The most economically stable nations (such as the United States, Norway, and Germany) all have CRP's of $0 \%$. By contrast, Argentina has a CPR of $17.63 \%$, the highest among the selected countries-and about four times higher than Brazil's. ${ }^{13}$ This means that if an investor wants to purchase a company in Argentina, they would demand an additional return of $17.63 \%$ compared to an identical deal in the United States (to compensate them for the inherent risk associated with the cost of doing business in Argentina).

\footnotetext{
12 The Argentinian Government has declared bankruptcy on its national debt numerous times, most recently in 2016, and has defaulted on its debt to creditors most recently in May of 2020.

${ }^{13}$ Argentina has in fact the second-highest CPR in a sample of about 200 countries, only below Sudan, Yemen, and Venezuela (all three tied in last place).
} 
Figure 3.3. Cross-Border M\&A Activity, by Acquiring Countries

(Number of Transactions and US\$ Billion)

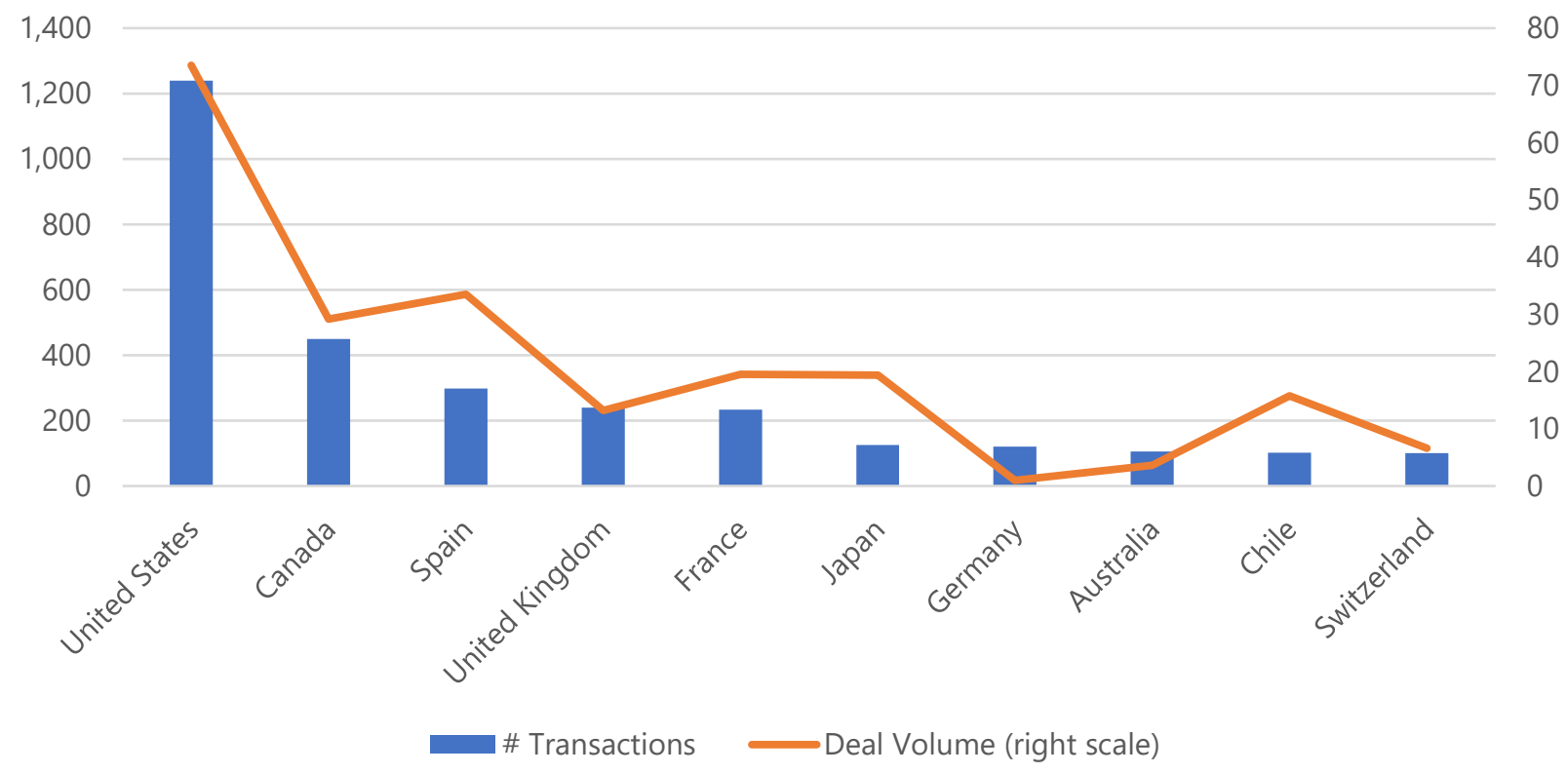

Source: EIKON (11.16.2020); authors' calculations

\section{Origin of Acquiring Firms}

Figure 3.3 illustrates the total cross-border M\&A transaction volume and deal volume on an aggregate dollar basis for the most frequent purchasers of the five largest economies of Latin America. US companies and private capital firms accounted for most of the M\&A activities, with over 1,200 transactions over the last ten years at an aggregate deal volume of over US $\$ 70$ billion. The second place is split between Canada in number of transactions, at 450, and Spain, in aggregate deal volume, at approximately US\$33.5 billion. 
Figure 3.4. Cross-Border M\&A Activity, by Target Industry

(Number of Transactions and US\$ Billion)

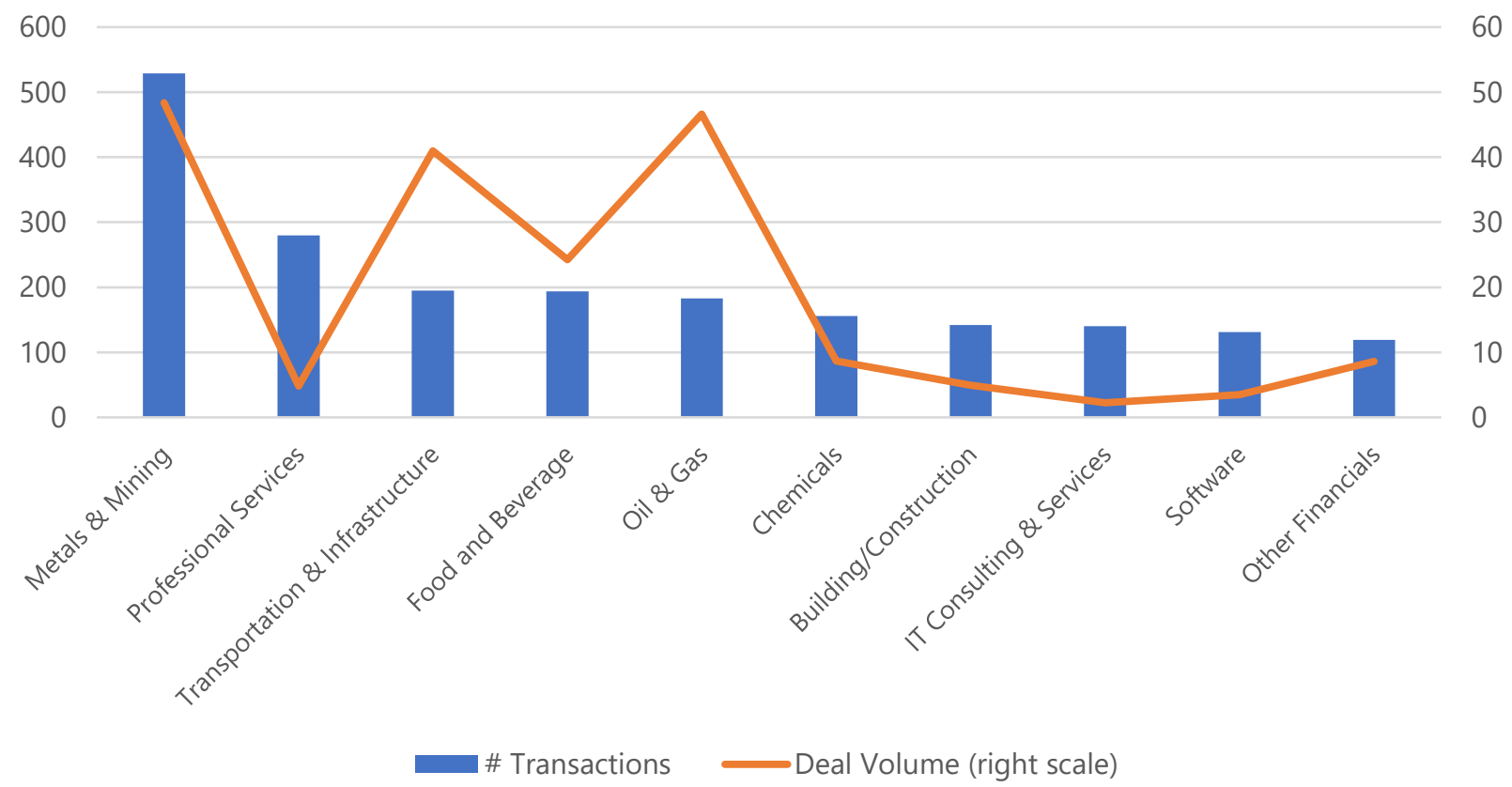

Source: EIKON (11.16.2020); authors' calculations

\section{Target Industries and Contract Structure}

Latin America is a region rich with natural reserves. Brazil is the world's leading producer of tin, iron ore, and phosphate. Chile is the world's largest producer of copper. Mexico is among the world's largest producers of oil, silver, copper, and zinc. Colombia is home to Latin America's largest coal reserves, and Argentina has rich deposits of lead, uranium, manganese, and tungsten. As such, natural resources are heavily represented in the (cross-border) M\&A landscape of the region (see figure 3.4). Metals \& Mining operations attract the greatest interest on a number of transactions basis, whereas the Oil \& Gas industry commands the largest aggregate deal volume on a \$US dollar-denominated basis.

Contracts concerning Metals \& Mining deals in Latin America are typically on a production basis, as opposed to a geographic mining location. Governments in the region tend to have separate guarantees built into contracts to protect purchasers against production uncertainty. These contracts can contain a minimum production threshold of resources obtained/produced, despite geographic limitations. This differs greatly from standard global Oil \& Gas deals, whereby rights are relegated to specified oil fields and do not contain any terminology that guarantees a minimum production threshold. Other contract 
variations include 'earn-outs' and increased percentage participation rights based upon successful geological surveys intended to provide mineral amount estimations.

An example of one such contract is covered below and supplied by GlobeNewswire ("Cerro Grande Mining Corporation Announces Letter of Intent," 2020):

On July 15 of 2020, Chilean company Cerro Grande Mining Corp entered into a Letter of Intent (LOI) with Minera Tamidak, the Pimentón Copper Mining Project's landowner. Tamidak acquired the mining project in bankruptcy proceedings back in 2018 and is now entering into a Joint Venture with Cerro to continue mining operations. In the JV agreement, following a 3D deep penetrating geophysical survey, Cerro will have the right to acquire up to $49 \%$ equity interest in the first 12 months. In addition to the initial $49 \%$, should Cerro be happy with the survey results and complete an in-house feasibility study with approval from the Chilean government, Cerro will have additional purchasing rights up to $70 \%$ after an additional US $\$ 5$ million consideration is paid to Tamidak. Finally, should both parties agree to a 'Decision to Mine' (decide it is worth the investment), Cerro will be able to increase its ownership to $75 \%$, assuming the company covers all commercial mining and production costs. In this instance, several key clauses of protection are included to neutralize uncertainty in the acquisition process. Tamidak owns the land and Cerro has the mining capabilities. Neither are certain of the size/value of the copper reserves in the ground.

\section{Deal-Making Process: The "ABCD" Companies in Latin America}

Typically, investment banking groups are structured in a way that caters to either a specific financial product (M\&A, IG/HY Debt, or Equity Capital Markets) or industry coverage (O\&G, Consumer Products, Technology, etc.). However, several investment banks deviate from the product/industry delineation with a separate "LatAm" coverage group specifically designed to serve the area. These groups specialize in how each country's transactional landscape operates and focus on the larger industries driving each economy.

LatAm-focused investment banking groups are also useful in navigating some of the informational holes of the M\&A space. As illustrated in Figure 3.2, government stability and ease of access to information are relevant topics when deciding whether to entertain a Latin American M\&A deal process. LatAm coverage groups help to close these informational gaps, and broader international corporations create Latin American subsidiaries to best position themselves for future buying opportunities to navigate the deal process.

The largest food and agricultural companies globally, Archer Daniels Midland (ADM), Bunge, Cargill, and Louis Dreyfus $(A B C D)$, provide a great illustration of this. These four companies have used more than ten separate subsidiaries to make 28 acquisitions and 12 minority investment/joint ventures in just Brazil, Mexico, Argentina, Colombia, and Chile in the last ten years. Cargill, the world's largest food and 
agricultural conglomerate and largest private company in the United States, was able to side-step maximum land ownership regulations in Colombia by setting up several shell companies to acquire more than 50,000 hectares of farming land. While Latin America is known for its natural resources, it is also a food and beverage production powerhouse.

Figure 3.5 combines the Food \& Beverage, Food \& Beverage Retailing, and Agriculture industries to capture its overall importance in the region. It represents better the reality of the agricultural industry in Latin America, ignoring its highly fragmented classification. The aforementioned ABCD companies operate entire industries: they have completed $M \& A$ transactions across nine separate industry groupings (Chemicals, Software, Machinery, Pharmaceuticals, Containers \& Packaging, Transportation \& Infrastructure, Food \& Beverage, Agriculture, \& Other Consumer Products) over the last ten years in Latin America. An apt comparison justifying the roll-up analysis would be Oil \& Gas, which is not broken out by level of the supply chain (Up-Stream, Mid-Stream, Down-Stream) over the past ten years.

\section{Figure 3.5. Cross-Border M\&A Activity, by Target Industry (combines Food \& Beverage, Food \& Beverage Retailing, \& Agriculture)}

(Number of Transactions and US\$ Billion)

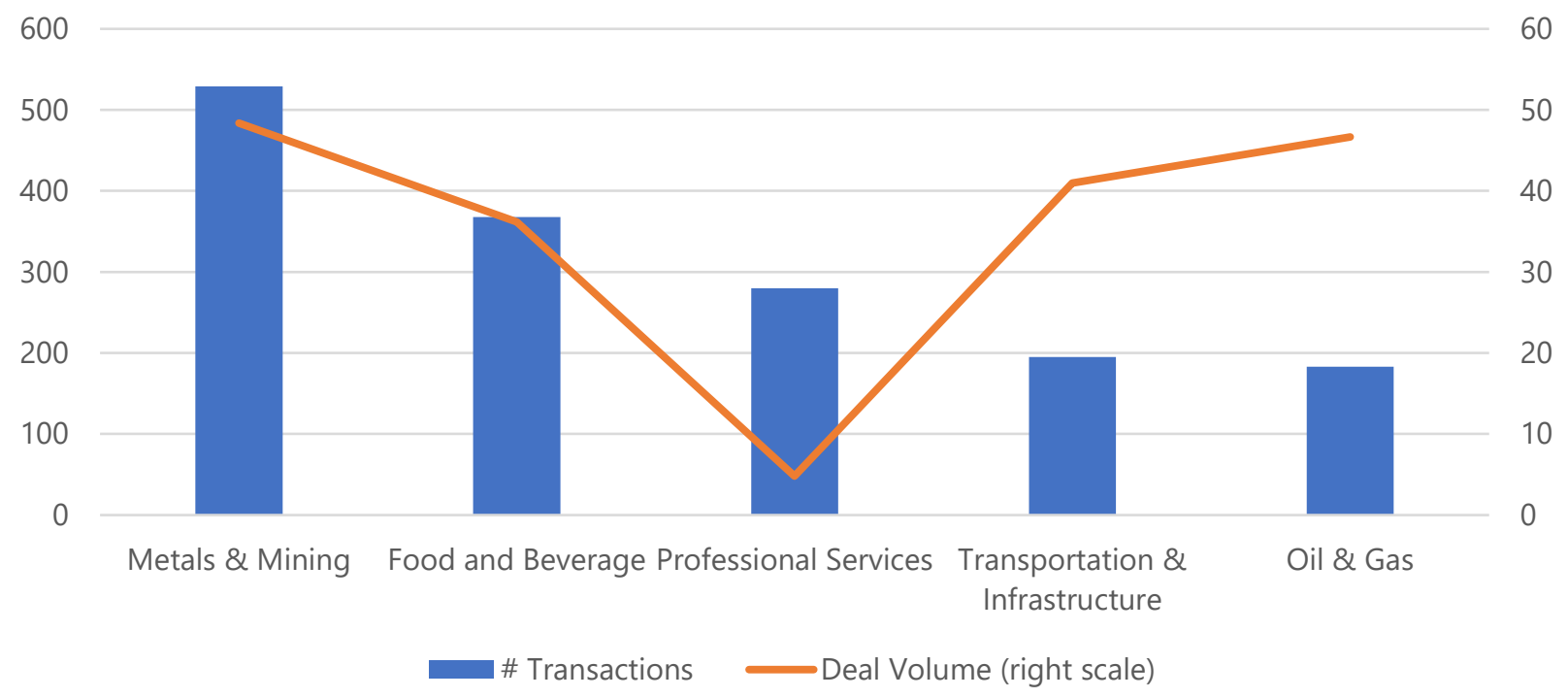

Source: EIKON (11.16.2020); authors' calculations

The $A B C D$ companies have demonstrated intense interest in Latin America across numerous industries within their supply chain. Cargill provides a useful illustration of a venture into the Technology industry: it completed an equity investment in Brazilian cloud-based farm production technology platform Agriness in 2018, designed to increase and track swine production KPI. Bunge entered into the Machinery industry when it bought a 30\% minority stake in Brazilian Farm Machinery supplier Agrofel in 2019, effectively controlling the farmers' before and after the grain production process. Another illustration is ADM and its 
entry into the Transportation and Infrastructure industry. ADM bought two separate Brazillian ports (Port Terminal Pará, Barcarena) in 2012 while also acquiring Brazilian port and shipping agency Blue Ocean Agencia Maritima in a 2020 joint venture with Norton Lilly International, a transportation conglomerate headquartered in Mobile, Alabama.

Furthermore, in January of 2020, ADM expanded their reach into the Chemicals industry when it acquired Brazilian chemical manufacturing company Yerbalatina Phytoactives. Yerbalatina focuses on the production of extracts and ingredients for customers in the food preservation vertical. Food and Beverage companies are heavily invested in the Latin American region along the entire supply chain, from production and equipment to chemical preservation, packaging, shipping, and even the tech that automates and controls the process.

Figure 3.6. Cross-Border M\&A Activity, by Acquirer Industry (Number of Transactions and US\$ Billion)

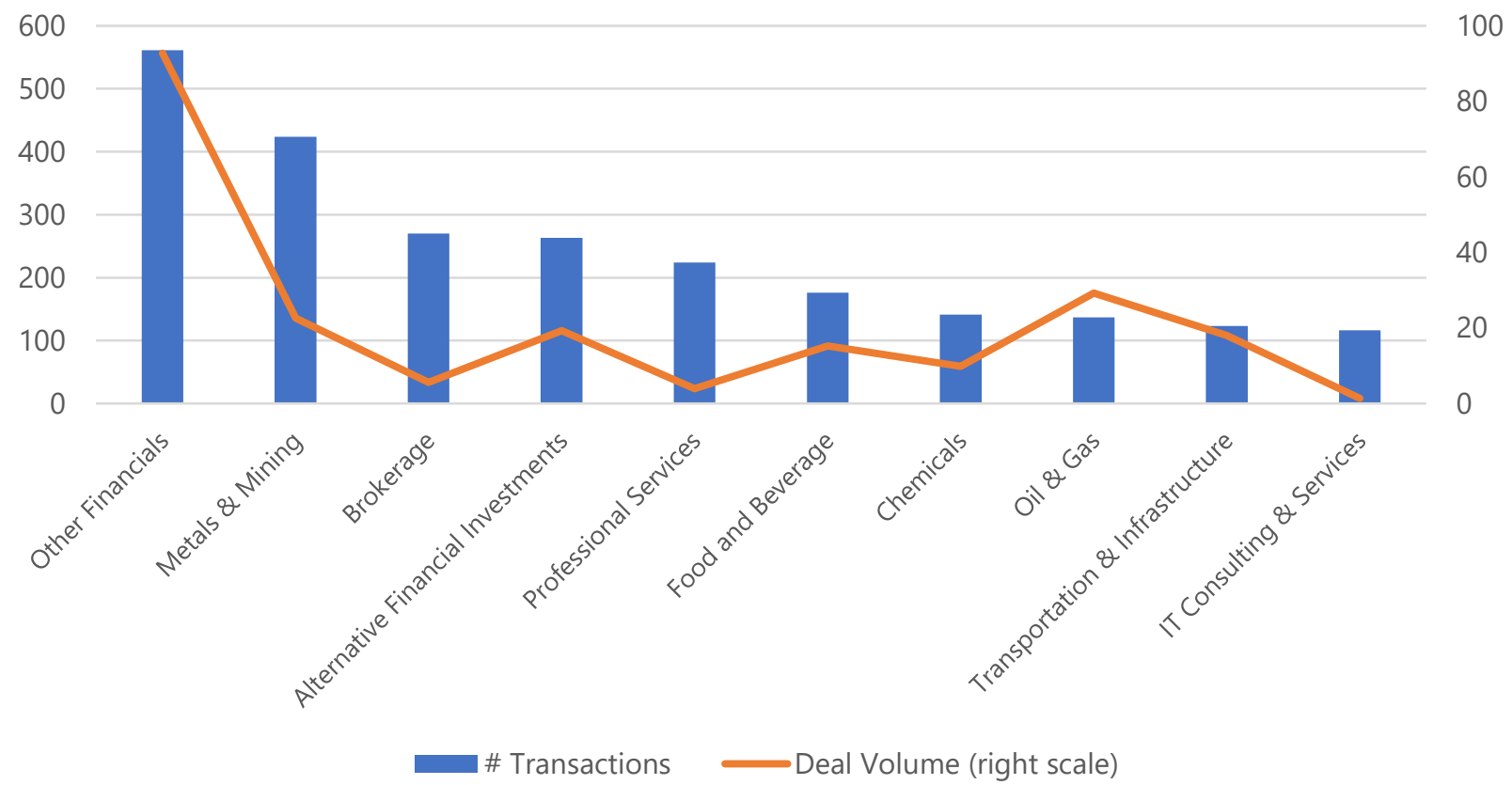

Source: EIKON (11.16.2020); authors' calculations

\section{Industry of Acquiring Firms}

Latin America attracts significant private capital investment in M\&A across the Private Equity spectrum (i.e., Angel Investment, Venture Capital, Growth Equity, and leveraged buy-out scenarios). "Other Financials," which can effectively be deemed a catch-all for this type of M\&A industry acquirer, is by far the leading purchaser in terms of cross-border aggregate deal volume and number of transactions (see figure 3.6). Capital-intensive industries (such as Metals \& Mining, Oil \& Gas, and Transportation \& 
Infrastructure) also exhibit significant M\&A volume in Latin America. Professional services attract significant M\&A volume on a transactional basis, illustrating a trend towards more developed economies in the region. Though not listed in the top 10 on number of transactions, the Telecommunications and Wireless industry in Mexico is quite large and concentrated, exhibiting four separate billion-dollar deals in the last ten years. AT\&T purchased Grupo Lusacell SA and Comunicaciones Nextel de Mexico, while America Movil SAB acquired Telefonos de Mexico SAB and Carso Global Telecom, amounting to almost $\$ 40$ Billion over 4 Mexican Telecom M\&A deals.

\section{Conclusion: The Road Ahead}

Access to foreign capital can have important implications for Latin America's economic performance. When accompanied by sound policies, global capital inflows can promote domestic economic growth and, more broadly, be used by local governments to foster their national economic agendas.

But before receiving any benefit, Latin American countries need first to attract international investors, which requires offering appropriate institutional and macroeconomic frameworks.

This report illustrates that when it comes to attracting foreign investors, Latin American countries compare well with other emerging markets and developing economies in the following categories:

- Workforce Talent, which captures the qualifications and diversity of the labor force.

- Financial Size and Condition, which reflects the breadth and depth of the existing financial system.

The overall performance in these categories is encouraging for Latin America, as it reflects the success of some initiatives undertaken by governments across the region over the past decades. It is also a good sign for investors, particularly those in sectors that prioritize highly skilled workers.

However, Latin American economies lag behind other emerging markets and developing economies in two crucial areas:

- Business Constraints, including the cost and time required to start a new business, and the percentage of firms that identify corruption, labor regulations, and taxes as an impediment to business.

- Investors' Rights, which account for the strength of investors' protection, property rights, and instability in government policymaking.

Improving in both areas is critical to increasing the region's attractiveness to foreign investors-and, more broadly, to generating a favorable investment climate. Doing so will take time and require long-term 
policies, as governments will need to enhance current legal frameworks and ensure their proper implementation over time. It will also require political will and significant changes to longstanding institutions, which are likely to generate opposition from local interest groups.

With over 100 positions separating the best and worst ranked country, it is clear that Latin American economies are highly heterogeneous. They differ in their natural resource endowments, degrees of economic openness, and overall levels of development, but also in their political systems, legal frameworks, and administrative procedures. These differences imply that the "correct" combination of policies required to address the issues mentioned above, as well as their implementations, will likely vary across countries. But while precise details may differ, our analysis confirms that most governments in the region will need to take tangible steps to address corruption, rebuild trust in government, and consolidate the rule of law. ${ }^{14}$

\footnotetext{
${ }^{14}$ For a brief discussion of corruption in Latin America, see Lagunes et al. (2019).
} 


\section{Appendix 1: Economy Grouping}

\section{Table A.1. List of Countries by Economic Group}

\begin{tabular}{lllll}
\hline \multicolumn{4}{c}{ Advanced Economies } \\
Australia & Finland & Italy & New Zealand & Switzerland \\
Austria & France & Japan & Norway & Taiwan \\
Belgium & Germany & Korea, Rep. & Portugal & United Kingdom \\
Canada & Greece & Latvia & Singapore & United States \\
Cyprus & Hong Kong & Lithuania & Slovak Republic & \\
Czech Republic & Iceland & Luxembourg & Slovenia & \\
Denmark & Ireland & Malta & Spain & \\
Estonia & Israel & Netherlands & Sweden &
\end{tabular}

\begin{tabular}{lllll} 
& \multicolumn{3}{c}{ Latin America } \\
Argentina & Chile & El Salvador & Mexico & Peru \\
Belize & Colombia & Guatemala & Nicaragua & Suriname \\
Bolivia & Costa Rica & Guyana & Panama & Uruguay \\
Brazil & Ecuador & Honduras & Paraguay & Venezuela
\end{tabular}

\begin{tabular}{lllll} 
& \multicolumn{3}{c}{ EMDE Asia (excl. China) } & Tuvalu \\
Bangladesh & Indonesia & Mongolia & Philippines & Vanuatu \\
Bhutan & Kiribati & Myanmar & Samoa & Vietnam \\
Brunei Darussalam & Lao P.D.R. & Nauru & Solomon Islands & \\
Cambodia & Malaysia & Nepal & Sri Lanka & \\
Fiji & Maldives & New Caledonia & Thailand & \\
French Polynesia & Marshall & Palau & Timor-Leste & \\
& Islands & Papua New & Tonga & \\
India & Micronesia & Guinea & &
\end{tabular}

\begin{tabular}{lllll}
\hline Albania & Bulgaria & Kosovo & North Macedonia & Russia \\
Belarus & Croatia & Moldova & Poland & Serbia \\
Bosnia and & Hungary & Montenegro & Romania & Turkey \\
Herzegovina & & & & Ukraine
\end{tabular}

\begin{tabular}{|c|c|c|c|c|}
\hline \multicolumn{5}{|c|}{ Rest of EMDE Economies } \\
\hline Afghanistan & Congo, Rep. & Iran, Islamic Rep. & Mauritius & South Africa \\
\hline Algeria & Côte d'Ivoire & Iraq & Morocco & South Sudan \\
\hline Angola & Djibouti & Jamaica & Mozambique & Sudan \\
\hline Armenia & Dominican Rep. & Jordan & Namibia & Syria \\
\hline
\end{tabular}




\begin{tabular}{|c|c|c|c|c|}
\hline Azerbaijan & Egypt & Kazakhstan & Niger & Tajikistan \\
\hline Bahrain & $\begin{array}{l}\text { Equatorial } \\
\text { Guinea }\end{array}$ & Kenya & Nigeria & Tanzania \\
\hline Benin & Eritrea & Kuwait & Oman & Togo \\
\hline Botswana & Eswatini & Kyrgyz Republic & Pakistan & $\begin{array}{l}\text { Trinidad and } \\
\text { Tobago }\end{array}$ \\
\hline Burkina Faso & Ethiopia & Lebanon & Qatar & Tunisia \\
\hline Burundi & Gabon & Lesotho & Rwanda & Turkmenistan \\
\hline Cabo Verde & Gambia, The & Liberia & $\begin{array}{l}\text { São Tomé and } \\
\text { Principe }\end{array}$ & Uganda \\
\hline Cameroon & Georgia & Libya & Saudi Arabia & Uzbekistan \\
\hline $\begin{array}{l}\text { Central African } \\
\text { Republic }\end{array}$ & Ghana & Madagascar & Senegal & $\begin{array}{l}\text { West Bank and } \\
\text { Gaza }\end{array}$ \\
\hline Chad & Guinea & Malawi & Seychelles & Yemen \\
\hline Comoros & Guinea-Bissau & Mali & Sierra Leone & Zambia \\
\hline Congo, Dem. Rep. & Haiti & Mauritania & Somalia & Zimbabwe \\
\hline
\end{tabular}

Source: IMF, WEO Groups and Aggregates Information (2020) 


\section{Bibliography}

Alfaro, Laura, and Maggie Xiaoyang Chen. "Surviving the Global Financial Crisis: Foreign Ownership and Establishment Performance." American Economic Journal: Economic Policy. 2012.

"Cerro Grande Mining Corporation Announces Letter of Intent to Acquire the Assets Relating to the Pimentón Copper Gold Mining Project." GlobeNewswire. July 15, 2020.

http://www.globenewswire.com/news-release/2020/07/15/2062662/0/en/Cerro-Grande-Mining-

Corporation-Announces-Letter-of-Intent-to-acquire-the-Assets-relating-to-the-Piment\%C3\%B3n-CopperGold-Mining-Project.html

Desai, Mihir A., C. Fritz Foley, and Kristin J. Forbes. "Financial Constraints and Growth: Multinational and Local Firm Responses to Currency Depreciations." The Review of Financial Studies. 2008.

Edwards, Sebastian. "Capital Inflows into Latin America: a Stop-Go Story? National Bureau of Economic Research, No. W6441, 1998.

Fox, Justin. "Lessons from Latin American Capital Flows." The Digest. October 1998.

Fruman, C., and X. Forneris. "The False Debate: Choosing Between Promoting FDI and Domestic Investment." World Bank: Private Sector Development Blog. June 06, 2016.

https://blogs.worldbank.org/psd/false-debate-choosing-between-promoting-fdi-and-domesticinvestment

Lagunes, Paul, Xiaoxuan Yang, and Andrés Castro. "The State of Corruption in Latin America." Baker Institute Report 7. 2019. https://www.bakerinstitute.org/media/files/files/09570f2e/bi-report-070819latam-corruption.pdf

Milken Institute Global Opportunity Index. 2021. https://milkeninstitute.org/reports/latin-america-globalopportunity-index/white-paper

Nelson, Rebecca M. "Argentina's Economic Crisis and Default." Congressional Research Service: Reports on Foreign Policy and Regional Affairs. June 15, 2020.

OCDE. Measurement and Identification of Capital Inflow Surges. October 2018.

OECD. "Foreign Direct Investment Flows in the Time of COVID-19." 2020. 
Smith, Benjamin. "Global Opportunity Index 2021: White Paper." Milken Institute. 2021.

UNCTAD. "Investor-State Dispute Settlement Cases Pass the 1,00 Mark: Cases and Outcomes in 2019." IIA Issues Note: International Investment Agreements. New York and Geneva: United Nations. 2020a.

UNCTAD. World Investment Report 2020: International Production Beyond the Pandemic. New York and Geneva: United Nations. 2020b.

\section{Acknowledgments}

The authors would like to thank Keith Savard, Jihad Dagher, Bill Lee, and Perry Wong for numerous discussions related to this topic. They would also like to thank participants at the Milken Institute's Research Department brown bag for useful comments.

\section{About the Authors}

Oscar Contreras, Ph.D., is an economist specializing in International Finance within the Research Department at the Milken Institute. He has experience in macroeconomics and financial markets, particularly in emerging economies. Before joining the Institute, Contreras was a senior economist at the Research Department of the Central Bank of Mexico, where he was responsible for providing macroeconomic analysis on monetary policy issues and conducting original research on macroeconomic and financial topics. Prior to his work at the Bank, he was an assistant professor at the University College for Financial Studies in Madrid, Spain. Contreras holds a Ph.D. in economics from Northwestern University and a BA (Hons) in economics from the Center for Economic Research and Teaching in Mexico City.

Joseph Bendix is a research analyst in International Finance within the Research Department at the Milken Institute. His work focuses on topics related to systemic risk, capital flows, and investment. More specifically, he is in charge of identifying and analyzing the market-level data sets in many of the research reports produced by the Institute. Bendix lends his experience to developing presentations for the Institute's conferences throughout the year. He holds a bachelor's in economics and a Master of Science in finance from the University of San Diego.

Benjamin Smith is a Research Analyst in International Finance within the Research Department at the Milken Institute. His areas of specialty include the intersection between technology and financial services, global economic policymaking, and foreign direct investment. Prior to joining the Milken Institute, Smith worked on trade policy issues with research institutes in the US and Canada, and published articles on US economic policy with a leading international affairs magazine. Smith holds an MA in Political Science from Colorado State University and a BA from Keele University. 
Claude Lopez, Ph.D., is the head of the Research Department at the Milken Institute, where she leads data-driven efforts aimed at influencing global policy issues on International Finance, Health Economics, and Regional Economics. She is an active member of the T20 task force on international financial architecture for stability and development, and a contributor to W20 (Women 20), two advisory committees to the G20. Lopez has over 20 years of experience in academic and policy research in the US and abroad. Before joining the Institute, Lopez headed multiple research teams at the Banque de France, the nation's central bank, and was a professor of economics at the University of Cincinnati. She has an MS in econometrics from Toulouse School of Economics and a Ph.D. in economics from the University of Houston. 